\title{
Intercomparison of carbonate chemistry measurements on a cruise in northwestern European shelf seas
}

\author{
M. Ribas-Ribas ${ }^{1}$, V. M. C. Rérolle ${ }^{1,2}$, D. C. E. Bakker ${ }^{3}$, V. Kitidis ${ }^{4}$, G. A. Lee ${ }^{3}$, I. Brown ${ }^{4}$, E. P. Achterberg ${ }^{1,5}$, \\ N. J. Hardman-Mountford ${ }^{4,6}$, and T. Tyrrell ${ }^{1}$ \\ ${ }^{1}$ Ocean and Earth Science, National Oceanography Centre Southampton, University of Southampton, Southampton, UK \\ ${ }^{2}$ National Oceanography Centre Southampton, Southampton, UK \\ ${ }^{3}$ Centre for Ocean and Atmospheric Sciences, School of Environmental Sciences, University of East Anglia, Norwich \\ Research Park, Norwich, UK \\ ${ }^{4}$ Plymouth Marine Laboratory, Prospect Place, Plymouth, UK \\ ${ }^{5}$ GEOMAR, Helmholtz Centre for Ocean Research, Kiel, Germany \\ ${ }^{6}$ CSIRO Oceans and Atmosphere Flagship, Floreat, WA 6014, Australia
}

Correspondence to: M. Ribas-Ribas (m.ribas-ribas@soton.ac.uk)

Received: 7 February 2014 - Published in Biogeosciences Discuss.: 19 February 2014

Revised: 20 June 2014 - Accepted: 3 July 2014 - Published: 19 August 2014

\begin{abstract}
Four carbonate system variables were measured in surface waters during a cruise aimed at investigating ocean acidification impacts traversing northwestern European shelf seas in the summer of 2011. High-resolution surface water data were collected for partial pressure of carbon dioxide ( $p \mathrm{CO}_{2}$; using two independent instruments) and $\mathrm{pH}$ using the total $\mathrm{pH}$ scale $\left(\mathrm{pH}_{\mathrm{T}}\right)$, in addition to discrete measurements of total alkalinity and dissolved inorganic carbon. We thus overdetermined the carbonate system (four measured variables, two degrees of freedom), which allowed us to evaluate the level of agreement between the variables on a cruise whose main aim was not intercomparison, and thus where conditions were more representative of normal working conditions. Calculations of carbonate system variables from other measurements generally compared well with direct observations of the same variables (Pearson's correlation coefficient always greater than or equal to 0.94 ; mean residuals were similar to the respective accuracies of the measurements). We therefore conclude that four of the independent data sets of carbonate chemistry variables were of high quality. A diurnal cycle with a maximum amplitude of $41 \mu$ atm was observed in the difference between the $\mathrm{CCO}_{2}$ values obtained by the two independent analytical $p \mathrm{CO}_{2}$ systems, and this was partly attributed to irregular seawater flows to the equilibrator and partly to biological activity inside the seawater supply and one of the equilibrators. We discuss how these
\end{abstract}

issues can be addressed to improve carbonate chemistry data quality on future research cruises.

\section{Introduction}

Accurate determination of the inorganic carbon system is a key requirement for ocean acidification studies, as it forms the basis for assessments of biological and biogeochemical responses to changes in ocean carbonate chemistry as a result of rising atmospheric $\mathrm{CO}_{2}$ concentrations. It is also essential for the determination of the air-sea fluxes of $\mathrm{CO}_{2}$, calculation of carbon budgets and estimation of anthropogenic $\mathrm{CO}_{2}$ concentrations in different water masses. When the carbonate system is overdetermined, it is possible to test if the different variables are consistent with one another. This requires that more than two of the measurable variables (total dissolved inorganic carbon $\left(C_{\mathrm{T}}\right)$, total alkalinity $\left(A_{\mathrm{T}}\right), \mathrm{pH}$ using the total $\mathrm{pH}$ scale $\left(\mathrm{pH}_{\mathrm{T}}\right)$, and partial pressure or fugacity of $\mathrm{CO}_{2}$ $\left.\left(p \mathrm{CO}_{2}, f \mathrm{CO}_{2}\right)\right)$ are determined.

Several at-sea intercomparison studies have taken place in recent years that compared different $p \mathrm{CO}_{2}$ instruments. Körtzinger et al. (1996) carried out what may have been the first intercomparison study in coastal waters between two similarly designed underway $p \mathrm{CO}_{2}$ systems. They found a remarkable agreement between the two simultaneously 
measured $p \mathrm{CO}_{2}$ data sets, even though the spatial variability in surface $p \mathrm{CO}_{2}$ in the North Sea was high. The average difference was $0.2 \mu \mathrm{atm}$ (standard deviation $=1.2 \mu \mathrm{atm}$ ), indicating no systematic difference. The difference tended to be highest during the most pronounced $p \mathrm{CO}_{2}$ gradients. Körtzinger et al. (2000) reported on a comprehensive shipboard, international intercomparison exercise which used one discrete and seven underway systems for the measurement of $f \mathrm{CO}_{2}$. This exercise showed that underway $f \mathrm{CO}_{2}$ can be determined to a high level of precision $( \pm 2 \mu \mathrm{atm})$ with a variety of equilibrator and system designs.

Other workers have undertaken at-sea intercomparisons of different variables. For instance, Johnson et al. (1999) compared $C_{\mathrm{T}}, f \mathrm{CO}_{2}$ and $A_{\mathrm{T}}$ measurements during the same intercomparison exercise as reported for $f \mathrm{CO}_{2}$ by Körtzinger et al. (2000). These scientists found a systematic $f \mathrm{CO}_{2}$ overestimation of $9 \mu \mathrm{atm}$ when calculated from $C_{\mathrm{T}}$ and $A_{\mathrm{T}}$ measurements relative to observed $f \mathrm{CO}_{2}$. Lamb et al. (2001) investigated 25 cruises in the Pacific Ocean where at least two of the four inorganic carbon variables were determined. They examined the consistency of the data set using certified reference material (CRM) analyses, precision of at-sea replicate analyses, agreement between shipboard analyses and replicate shore-based analyses, comparison of deep water values at locations where two or more cruises overlapped or crossed, consistency with other hydrographic parameters, and internal consistency between multiple carbon variable measurements. Using all this evidence, the carbonate data was adjusted for inconsistencies, and a combined data set was constructed, which showed that $C_{\mathrm{T}}$ and $A_{\mathrm{T}}$ had an estimated overall accuracy of 3 and $5 \mu \mathrm{mol} \mathrm{kg}{ }^{-1}$, respectively.

Other studies pointed out some inconsistencies: Millero et al. (2002) noted that the use of $\mathrm{pH}_{\mathrm{T}}$ and $C_{\mathrm{T}}$ from field measurements from the Atlantic, Indian, Southern and Pacific oceans yielded standard errors $(1 \sigma)$ of $\pm 22.3 \mu$ atm in calculated $p \mathrm{CO}_{2}$ and $\pm 4.3 \mu \mathrm{mol} \mathrm{kg}{ }^{-1}$ in calculated $A_{\mathrm{T}}$. Lueker et al. (2000) noted that observed values of $p \mathrm{CO}_{2}$ above $500 \mu \mathrm{atm}$ were, on average, $3.35 \%$ (if $p \mathrm{CO}_{2}$ is $500 \mu \mathrm{atm}$, that will be $17 \mu \mathrm{atm}$ ) higher than $p \mathrm{CO}_{2}$ calculated from $C_{\mathrm{T}}$ and $A_{\mathrm{T}}$. This tendency towards larger differences between measured $p \mathrm{CO}_{2}$ and calculated $p \mathrm{CO}_{2}$ at higher $p \mathrm{CO}_{2}$ levels was also observed by McElligott et al. (1998), suggesting that it might result from an inaccuracy in the formulation of the solubility coefficient of $\mathrm{CO}_{2}$ in seawater $\left(K_{0}\right)$. However, this apparent discrepancy has not yet been explained satisfactorily (Dickson, 2010). It is possible that an unidentified acid-base system affects the calculation of $p \mathrm{CO}_{2}$, or that one or more dissociation constants for acid-base equilibria are not well parameterised at high $p \mathrm{CO}_{2}$ (Dickson, 2010).

The aims of our study were to evaluate the quality of our observations of inorganic carbon variables and to investigate differences between observed and calculated variables in order to identify means of improving data quality. Our study differs from some previous work in two respects: firstly, our study was undertaken in surface waters of shelf seas where spatial variability is high; and, secondly, the study was not designed at the outset as an intercomparison exercise, which normally involves placing all the instruments in one laboratory, sampling from a single seawater supply, and an intense focus on every aspect of the carbonate chemistry measurements. Instead, the instruments were in three separate laboratories, with samples taken from four different seawater outlets and the operators conducting multiple tasks as part of the multidisciplinary research activities undertaken on the cruise. Our findings are therefore more representative of a typical multidisciplinary research cruise.

\section{Material and methods}

The data used in this study were collected in the period 6 June to 7 July 2011 during RRS Discovery research cruise D366 in northwestern European shelf seas. The cruise formed part of the UK Ocean Acidification Research Programme. Two variables of the carbonate system $\left(p \mathrm{CO}_{2}\right.$ and $\left.\mathrm{pH}_{\mathrm{T}}\right)$, plus salinity and sea surface temperature, were measured at a high temporal resolution (every $5 \mathrm{~min}$ for one $p \mathrm{CO}_{2}$ system $\left(p \mathrm{CO}_{2}-1\right)$, every $6 \mathrm{~min}$ for $\mathrm{pH}_{\mathrm{T}}$, and every $1 \mathrm{~min}$ for a second $p \mathrm{CO}_{2}$ $\left(p \mathrm{CO}_{2}-2\right)$ system). These instruments received a continuous flow of water from the ship's underway continuous seawater supply (intake positioned at ca. $5 \mathrm{~m}$ in depth). In addition, nutrients (nitrate plus nitrite, phosphate and silicate), $C_{\mathrm{T}}$ and $A_{\mathrm{T}}$ were sampled every $2 \mathrm{~h}$ from the underway supply, and also collected in surface waters sampled by conductivitytemperature-depth (CTD) casts (samples obtained from the sampling bottle closest to $5 \mathrm{~m}$ in depth; typically between 2.0 and $8.2 \mathrm{~m}$ ). Continuous temperature and conductivity data were obtained from a Sea-Bird Electronics SBE45 thermosalinograph (TSG) installed on the ship's underway supply. Discrete surface water samples for salinity $(S)$ were collected every $4 \mathrm{~h}$ in order to calibrate the conductivity measurements. Discrete salinity samples were analysed using a salinometer (Guildline Autosal 8400B). Photosynthetically active irradiance (PAR), radiation between 400 and $700 \mathrm{~nm}$, was measured as part of the ship's meteorological parameters with a 2-pi sensor (Skye Instruments, model SKE 510) positioned at $10 \mathrm{~m}$ in height.

\subsection{Carbonate chemistry analysis}

\subsubsection{Partial pressure of $\mathrm{CO}_{2}$}

Quasi-continuous measurements of $p \mathrm{CO}_{2}$ in surface water and marine air were undertaken using two different instruments (hereafter $p \mathrm{CO}_{2}-1$ and $p \mathrm{CO}_{2}-2$ ). The $p \mathrm{CO}_{2}-1$ and $p \mathrm{CO}_{2}-2$ systems undertook 6187 and 26671 measurements of surface water $p \mathrm{CO}_{2}$ during the cruise, respectively.

System 1: system $p \mathrm{CO}_{2}-1$ was an underway $p \mathrm{CO}_{2}$ instrument (PML-Dartcom Live $p \mathrm{CO}_{2}$ ) as described in detail by Hardman-Mountford et al. (2008), with the modified "vented" equilibrator introduced by Kitidis et al. (2012). The 
instrument was located in a mid-ship chemistry laboratory. The system used a vented-showerhead equilibrator, with ambient light blocked out, to equilibrate seawater $\mathrm{CO}_{2}$ with a headspace. In order to maintain atmospheric pressure in the equilibrator headspace, the unit was vented to a second equilibrator, which in turn was vented to the atmosphere via a $2 \mathrm{~m}$ coil of stainless steel tubing ( $1.5 \mathrm{~mm}$ internal diameter). The equilibrator was fitted with two platinum resistance thermometers (Pico Technology, model PT100) and insulated with a water-jacket supplied with seawater from the ship's underway seawater system. A seawater flow of $1.6 \mathrm{~L} \mathrm{~min}^{-1}$ was maintained across the equilibrator. The average warming between the ship's underway seawater intake and the equilibrator was $0.5^{\circ} \mathrm{C}$ (standard deviation $0.1^{\circ} \mathrm{C}$ ). Atmospheric measurements of $\mathrm{CO}_{2}$ were taken from an intake located forward on the deck above the ship's bridge. Both gas streams from the equilibrator headspace and the air inlet were dried in a Peltier cooler $\left(-20^{\circ} \mathrm{C}\right)$. Mixing ratios of $\mathrm{CO}_{2}$ and water in the marine air and equilibrator headspace were determined by infrared detection (LI-840, LI-COR). Measurements were referenced against secondary calibration gases from BOC Industrial Gases (UK), with known $\mathrm{CO}_{2}$ mixing ratios $\left(0,251.3\right.$ and $\left.446.9 \mu \mathrm{mol} \mathrm{CO} \mathrm{mol}^{-1}\right)$ in synthetic air mixtures (21\% oxygen and $79 \%$ nitrogen). All calibration gases underwent pre- and post-cruise calibration against certified primary standards from the National Oceanic and Atmospheric Administration (NOAA), which had values of 244.9 and $444.4 \mu \mathrm{mol} \mathrm{CO} \mathrm{mol}^{-1}$.

System 2: system $p \mathrm{CO}_{2}-2$ was an underway $p \mathrm{CO}_{2}$ system located in a container laboratory positioned on the aft deck of the ship. The instrument setup and calibration procedures are as described by Bakker et al. (2007), with the exception of the vented equilibrator. The percolating packed bed-type equilibrator was identical to the one described by Schuster and Watson (2007). The equilibrator of transparent perspex was positioned next to the window of the container without blinds. Atmospheric samples were taken from an air inlet located forward on the deck above the ship's bridge. Samples from the equilibrator headspace and marine air were partially dried by being passed through an electric cool box at about $2{ }^{\circ} \mathrm{C}$ prior to analysis. Mixing ratios of $\mathrm{CO}_{2}$ and water in the marine air and equilibrator headspace were determined by infrared detection with a LI-COR LI7000. The LI-COR was calibrated using secondary gas standards from BOC Industrial Gases (UK) with $\mathrm{CO}_{2}$ mixing ratios of 2.4, 260.9, 364.2 and $473.1 \mu \mathrm{mol} \mathrm{CO} \mathrm{mol}^{-1}$ in an artificial air mixture $(21 \%$ oxygen, $79 \%$ nitrogen). All calibration gases underwent preand post-cruise calibration against certified primary standards from the NOAA, which had values of 251.6, 347.2 and $448.8 \mu \mathrm{mol} \mathrm{CO} \mathrm{mol}^{-1}$. The seawater flow to the container laboratory was highly variable throughout the cruise. This was due to the location of the container downstream of an intermittently large water demand for an experiment. The water flow was regulated to a maximum of $1.8 \mathrm{~L} \mathrm{~min}^{-1}$, to avoid flooding of the equilibrator and $\mathrm{CO}_{2}$ analyser during sudden spikes in supply. The water flow tended to decrease gradually to very low flow over 6 to $12 \mathrm{~h}$. Two platinum resistance thermometers positioned in the upper and lower part of the seawater stream determined the temperature of the seawater in the equilibrator (a PT probe (Omega) with modified electronics). Average warming of the seawater between the intake and the equilibrator was estimated as $0.5^{\circ} \mathrm{C}$ (standard deviation $0.4^{\circ} \mathrm{C}$ ). The large temperature deviations reflected the irregular seawater flow to the equilibrator. In addition, the post-cruise temperature calibration of the PT100 sensors showed an excessive drift of $4-5{ }^{\circ} \mathrm{C}$ relative to the pre-cruise calibration. The absolute calibration of the temperature sensors was therefore deemed unreliable. Equilibrator temperatures from 13 June (09:57 GMT) to 17 June (17:12 GMT) have been reduced by $0.7^{\circ} \mathrm{C}$, while equilibrator temperatures after 19 June (21:57 GMT) have been increased by $0.7^{\circ} \mathrm{C}$ to remove the negative temperature changes.

The precision of both LI-COR $p \mathrm{CO}_{2}$ measurements was $1 \mu \mathrm{atm}$, established using standard gases. We estimated different accuracies for the two systems: $4 \mu \mathrm{atm}$ for system $p \mathrm{CO}_{2}-1$ and $10 \mu \mathrm{atm}$ for system $p \mathrm{CO}_{2}-2$. The $p \mathrm{CO}_{2}$ was computed from the $\mathrm{CO}_{2}$ mixing ratios and the ship's barometric pressure corrected from $18 \mathrm{~m}$ in height to sea level, and corrected for seawater vapour pressure (Weiss and Price, 1980). Sea surface $p \mathrm{CO}_{2}$ data were corrected to sea surface temperature to account for the warming between the seawater intake and the equilibrators (Takahashi et al., 1993). The accuracies of the temperature measurements inside the equilibrators were estimated to be $0.02{ }^{\circ} \mathrm{C}$ and $5^{\circ} \mathrm{C}$ for $p \mathrm{CO}_{2}-1$ and $p \mathrm{CO}_{2}-2$, respectively.

$p \mathrm{CO}_{2}-1$ measurements were backdated by $1 \mathrm{~min}$ and $p \mathrm{CO}_{2}-2$ measurements by $3 \mathrm{~min}$ to account for the travel time of the seawater between the seawater intake and the respective equilibrators. The time offsets ( 1 and $3 \mathrm{~min}$ ) between seawater intake and equilibrators were chosen objectively as those producing the minimum standard deviation between paired equilibrator and intake temperatures. The intercomparison exercise was carried out on the data sets after they had been adjusted according to the procedures just described, including corrections to the in situ seawater temperature described above.

\subsection{2 $\mathrm{pH}_{\mathrm{T}}$}

Surface water $\mathrm{pH}_{\mathrm{T}}$ was measured continuously with an automated instrument located in the mid-ship chemistry laboratory and connected to the ship's underway seawater supply. The $\mathrm{pH}_{\mathrm{T}}$ system undertook 29950 measurements. The surface distribution and the processes that control $\mathrm{pH}_{\mathrm{T}}$ in this cruise have been described by Rérolle et al. (2014). The measurement technique, described by Rérolle et al. (2013), was based on a colorimetric method using thymol blue as a $\mathrm{pH}$ indicator (Clayton and Byrne, 1993; Rérolle et al., 2012). $\mathrm{pH}_{\mathrm{T}}$ was determined on the total $\mathrm{pH}$ scale. Measurements were made every $6 \mathrm{~min}$ with a precision of $1 \mathrm{mpH}$ (Rérolle 
et al., 2013). Three bottles of Tris $\mathrm{pH}$ buffer provided by Andrew Dickson (Scripps Institution of Oceanography, Marine Physical Laboratory, University of California San Diego, USA) were analysed at the beginning, middle and end of the cruise to check the accuracy of the $\mathrm{pH}_{\mathrm{T}}$ measurements, which was $4 \mathrm{mpH}$. The thymol blue extinction coefficients were determined in the laboratory following the cruise, applying the salinity and temperature ranges observed during the cruise, with the indicator's dissociation constant taken from Zhang and Byrne (1996). Measurements at sea were made at the seawater temperature plus $0.2^{\circ} \mathrm{C}$, due to warming between the seawater intake and the $\mathrm{pH}$ instrument. In order to minimise absorbance interference by particulates, an in-line filter $(0.45 \mu \mathrm{m}$ pore size, Millex HP syringe filter Millipore Express $^{\circledR}$ (PES) membrane $33 \mathrm{~mm}$ diameter, Millipore) was placed at the entry of the sample tube. Chromophoric dissolved organic matter (CDOM) only absorbs weakly in the visible spectrum where thymol blue absorbance is measured $(<3 \%$ at $435 \mathrm{~nm}$ and $<1 \%$ at $596 \mathrm{~nm})$, and is accounted for in the seawater blank. CDOM absorbance interference is thereby cancelled out. Additionally, measurements at wavelength $750 \mathrm{~nm}$ (not affected by the thymol blue indicator) were used to monitor for sample turbidity and instrument drift.

\subsubsection{Dissolved inorganic carbon and total alkalinity}

Samples for $C_{\mathrm{T}}$ and $A_{\mathrm{T}}$ analysis were collected from the underway seawater supply (322 samples in total), and shallow depths sampled (64 samples) using Ocean Test Equipment bottles on the CTD frame following procedures detailed in Bakker et al. (2007). All samples were fixed with $50 \mu \mathrm{L}$ of saturated mercuric chloride $\left(\mathrm{HgCl}_{2}\right)$ solution per $250 \mathrm{~mL}$ seawater. The samples were analysed in duplicate on replicate $250 \mathrm{~mL}$ sample bottles. Two VINDTA 3C (Versatile Instrument for the Determination of Titration Alkalinity; Marianda) were used to determine $C_{\mathrm{T}}$ and $A_{\mathrm{T}}$, with CRM (batch 107) analysed in duplicate for $C_{\mathrm{T}}$ and $A_{\mathrm{T}}$ at the beginning, middle and end of each use of a coulometric cell. One VINDTA was used for surface water samples and the other one for CTD casts. For consistency, we checked offsets between those underway and CTD samples which were less than $30 \mathrm{~min}$ apart. Because underway sampling was often stopped when we were on station, only 19 stations could be checked. The average offsets between CTD and surface water samples from the continuous supply were 0.3 and $0.5 \mu \mathrm{mol} \mathrm{\textrm {kg } ^ { - 1 }}$ for $C_{\mathrm{T}}$ and $A_{\mathrm{T}}$, respectively. This is below the accuracy of the method, and so we merged the data from the two types of sampling and the two VINDTA 3C instruments. The concentration of $C_{\mathrm{T}}$ was determined using coulometric analysis (Johnson et al., 1987). Analysis for $A_{\mathrm{T}}$ was carried out by potentiometric titration with hydrochloric acid to the carbonic acid end point (Dickson, 1981). The accuracies of the $C_{\mathrm{T}}$ and $A_{\mathrm{T}}$ measurements were 2.0 and $1.5 \mu \mathrm{mol} \mathrm{kg}^{-1}$, and the precisions 1.7 and $1.2 \mu \mathrm{mol} \mathrm{kg}^{-1}$, respectively (159 CRMs anal- ysed in duplicate). The combined carbonate chemistry data set is available via Ribas-Ribas et al. (2014).

\subsection{Nutrients}

Analyses of nitrate and nitrite, phosphate and silicate were undertaken using a segmented flow auto-analyser (Skalar San+) following following standard protocols (Grasshoff et al., 1983). Samples were stored in $25 \mathrm{~mL}$ polycarbonate vials and kept refrigerated at approximately $4{ }^{\circ} \mathrm{C}$ until analysis (conducted within $12 \mathrm{~h}$ after sampling). Nutrient concentrations were used for the calculations of the carbonate chemistry system.

\subsection{Carbonate chemistry calculations}

We applied the CO2SYS program (MATLAB version) (Lewis and Wallace, 1998; Van Heuven et al., 2011) to all possible pairs of $\mathrm{pH}_{\mathrm{T}}, p \mathrm{CO}_{2}, C_{\mathrm{T}}$ and $A_{\mathrm{T}}$ measurements to calculate the other variables, using the carbonate equilibrium constants described by Mehrbach et al. (1973) and refitted by Dickson and Millero (1987) (hereafter Mehrbach constants). We used the Mehrbach constants because they led to the smallest inconsistencies between different high-accuracy measurements in previous observational studies (Clayton et al., 1995; Lee et al., 1997; McElligott et al., 1998; Wanninkhof et al., 1999). However, we also compared against results calculated using constants from Roy et al. (1993), Lueker et al. (2000) and Millero et al. (2006) (Sect. 3.3).

For the dissociation constant of boric acid, we used Dickson (1990b), for bisulphate ions Dickson (1990a), and for the ratio of total boron to salinity, we used Uppström, but also compared against results calculated using Lee et al. (2010) (Sect. 3.3).

\subsection{Intercomparison}

The sampling frequencies of $p \mathrm{CO}_{2}-1$ and $\mathrm{pH}_{\mathrm{T}}$ were both around $5 \mathrm{~min}$, but the measurements were not synchronised, and were undertaken simultaneously (within $1 \mathrm{~min}$ ) on only 208 occasions. However, it was possible to interpolate $\mathrm{pH}_{\mathrm{T}}$ determinations (with a maximum interval of $5 \mathrm{~min}$ ) and thereby obtain values at comparable times.

Data from the underway temperature, salinity, PAR, $p \mathrm{CO}_{2}$ and $\mathrm{pH}_{\mathrm{T}}$ measurements were retrieved at the times of nutrient, $C_{\mathrm{T}}$ and $A_{\mathrm{T}}$ measurements.

Statistical analyses were used to determine the level of agreement between observed and calculated carbonate system variables:

- Pearson's correlation coefficient $(r)$ : a measure of the degree of linear dependence between two variables.

- Mean residual (MR): average difference between two variables, e.g. between the observed values and the values calculated from measurements of a pair of other 
carbonate variables. MR will be negative if the observed values are on average lower than the calculated values.

- Root mean square error (RMSE): square root of the mean of the squared differences between the observed and calculated values.

Some properties of individual variables (as opposed to comparisons) are also used in Sect. 3.

- Accuracy is an expression of the lack of bias, and relates to the degree of agreement of a measured value with the true value (as determined using a CRM).

- Uncertainty characterises the range of values within which the true value is asserted to lie with some level of confidence. Uncertainty is derived from inaccuracy and imprecision of measurements, and also from propagation of errors for calculated variables.

In this study, uncertainties in calculated values were determined by a Monte Carlo approach as follows: (1) the original carbonate chemistry variable values in the data set were input into the CO2SYS program (MATLAB version) (Van Heuven et al., 2011); (2) artificial random errors (normally distributed according to the central limit theorem, with a mean of zero and standard deviation equal to the accuracy of measurement) were calculated using a random number generator; and (3) new carbonate chemistry variable values (the original ones plus the randomly generated errors) were input into CO2SYS. Calculated $p \mathrm{CO}_{2}-1$ and calculated $p \mathrm{CO}_{2}-2$ have the same uncertainty because they depend only on the accuracies of the variables from which they are calculated. They are therefore identical for both $p \mathrm{CO}_{2}$ systems. The calculated uncertainty of parameters calculated from $p \mathrm{CO}_{2}-$ 2 as one of the input variables is higher than those from $p \mathrm{CO}_{2}-1$ because the measurement accuracy was higher. This Monte Carlo approach was previously used by Juranek et al. (2009) to calculate uncertainties in calcium carbonate saturation states.

In this paper, we use accuracies and calculated uncertainties as benchmarks. We use them to provide an assessment of what is reasonable to expect for a match between observed and calculated values. We compare values of accuracy with MRs, and calculated uncertainties with RMSEs, to evaluate if the calculated variables are in "good" agreement with the measured variables. All comparisons resulted in MR less than or equal to accuracy (with the exception of predictions based on of all prediction based on $p \mathrm{CO}_{2}$ and $\mathrm{pH} ; A_{\mathrm{T}}$ from $C_{\mathrm{T}}$ and $\left.p \mathrm{CO}_{2}-1\right)$. In terms of RMSE, all comparisons resulted in RMSE less than twice the uncertainty, except those involving measured $p \mathrm{CO}_{2}-2$. On this basis, we conclude that there is generally good agreement between measured and calculated variables, except those comparisons involving measured $p \mathrm{CO}_{2}-2$ or calculations from $\mathrm{pH}_{\mathrm{T}}$ and $p \mathrm{CO}_{2}$. For example, if the MR and RMSE between measured and calculated (from $A_{\mathrm{T}}$ and $p \mathrm{CO}_{2}-1$ ) $C_{\mathrm{T}}$ are $-1.7 \mu \mathrm{mol} \mathrm{kg}^{-1}$ and

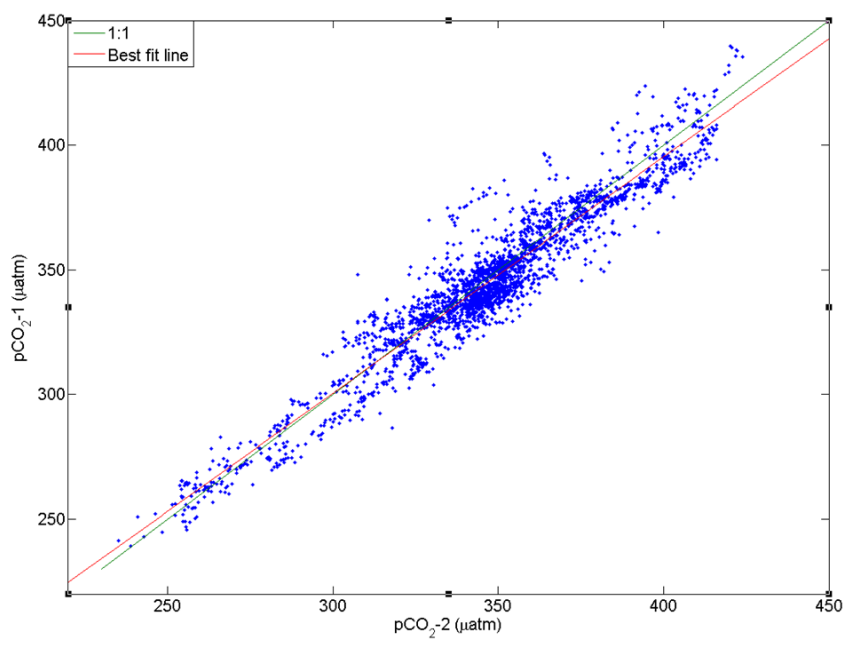

Figure 1. Relationship between two independently measured $p \mathrm{CO}_{2}$ data sets. The line of perfect agreement (1:1 line, in green) and the best fit line (in red) are also shown.

$3.9 \mu \mathrm{mol} \mathrm{kg}-1$, whereas the accuracy is $2.0 \mu \mathrm{mol} \mathrm{kg}-1$ and the calculated uncertainty is $2.5 \mu \mathrm{mol} \mathrm{kg}{ }^{-1}$, then we conclude that there is good agreement between the calculated and measured $C_{\mathrm{T}}$ values. As another example, an RMSE of 0.008 and an MR of 0.001 demonstrate good agreement between measured and calculated (from $C_{\mathrm{T}}$ and $A_{\mathrm{T}}$ ) $\mathrm{pH}_{\mathrm{T}}$ if the calculated uncertainty according to the Monte Carlo approach is 0.005 and the measurement accuracy is 0.004 . A smaller MR on its own does not demonstrate a better agreement; it should always be put into context with RMSE, accuracy and uncertainty.

\section{Results and discussion}

\subsection{Comparison between the two $p \mathrm{CO}_{2}$ systems}

The $p \mathrm{CO}_{2}$ data sets obtained using the $p \mathrm{CO}_{2}-1$ and $p \mathrm{CO}_{2}-2$ systems were significantly correlated $(r=0.956, p<0.001$, $\mathrm{d} f=2679$ ) (Fig. 1). We used a major axis model II regression because both $p \mathrm{CO}_{2}$ data sets included uncertainty ( $p \mathrm{CO}_{2}-1$ and $p \mathrm{CO}_{2}-2$ were not one dependent controlled and one independent variable). We used the $\mathrm{R}$ code for model II regression (Legendre, 2014). The resulting equation of the regression is $p \mathrm{CO}_{2}-1=0.9( \pm 2.1)+0.99( \pm 0.01) \times p \mathrm{CO}_{2}$ 2. Confidence intervals are used for testing the null hypothesis of a slope of 1 and a $y$ intercept of 0 (Quinn and Keough, 2002). The $95 \%$ confidence interval of the slope does include the value 1 and the $95 \%$ confidence interval of the intercept does include the value 0 . The comparison between both sets of $p \mathrm{CO}_{2}$ data revealed a mean residual of $-2 \mu \mathrm{atm}\left(p \mathrm{CO}_{2}-1\right.$ minus $\left.p \mathrm{CO}_{2}-2\right)$. The RMSE was $10 \mu$ atm. 
Table 1. Results of comparisons between direct measurements and values calculated (using the CO2SYS software) from measurements of other variables. $r$ is Pearson's correlation coefficient, $\mathrm{df}$ is degrees of freedom, RMSE is root mean square error and MR is mean of the residuals. The measurement accuracy is from Sect. 2.1. Note that calculated $p \mathrm{CO}_{2}-1$ and calculated $p \mathrm{CO}_{2}-2$ have the same uncertainty because they depend only on the accuracies of the variables from which they are calculated. They are therefore identical for both $p \mathrm{CO}_{2}$ systems. Calculated uncertainty of parameters calculated using $p \mathrm{CO}_{2}-2$ as an input variable is higher than those using $p \mathrm{CO}_{2}-1$, because the measurement accuracy is higher.

\begin{tabular}{|c|c|c|c|c|c|c|c|}
\hline \multirow[b]{2}{*}{$\begin{array}{l}\text { Measured } \\
\text { variable }\end{array}$} & \multirow[b]{2}{*}{$\begin{array}{l}\text { Input variables } \\
\text { for calculation }\end{array}$} & \multicolumn{4}{|c|}{ Comparison statistics } & \multicolumn{2}{|c|}{ Benchmarks } \\
\hline & & $r$ & $\mathrm{~d} f$ & RMSE* & $\mathrm{MR}^{*}$ & $\begin{array}{r}\text { Calculated } \\
\text { uncertainty* }\end{array}$ & $\begin{array}{l}\text { Measurement } \\
\text { accuracy }^{*}\end{array}$ \\
\hline \multirow[t]{3}{*}{$p \mathrm{CO}_{2}-1(\mu \mathrm{atm})$} & $C_{\mathrm{T}}$ and $\mathrm{pH}_{\mathrm{T}}$ & 0.984 & 31 & 5 & 3 & 4 & \\
\hline & $A_{\mathrm{T}}$ and $\mathrm{pH}_{\mathrm{T}}$ & 0.990 & 27 & 6 & 2 & 4 & 4 \\
\hline & $C_{\mathrm{T}}$ and $A_{\mathrm{T}}$ & 0.987 & 43 & 6 & 3 & 4 & \\
\hline \multirow[t]{3}{*}{$p \mathrm{CO}_{2}-2(\mu \mathrm{atm})$} & $C_{\mathrm{T}}$ and $\mathrm{pH}_{\mathrm{T}}$ & 0.949 & 97 & 11 & 4 & 4 & \\
\hline & $A_{\mathrm{T}}$ and $\mathrm{pH}_{\mathrm{T}}$ & 0.947 & 93 & 11 & 4 & 4 & 10 \\
\hline & $C_{\mathrm{T}}$ and $A_{\mathrm{T}}$ & 0.937 & 156 & 12 & 1 & 4 & \\
\hline \multirow[t]{5}{*}{$\mathrm{pH}_{\mathrm{T}}$} & $C_{\mathrm{T}}$ and $A_{\mathrm{T}}$ & 0.952 & 218 & 0.008 & 0.001 & 0.005 & \\
\hline & $A_{\mathrm{T}}$ and $p \mathrm{CO}_{2-1}$ & 0.991 & 27 & 0.006 & 0.002 & 0.003 & \\
\hline & $A_{\mathrm{T}}$ and $p \mathrm{CO}_{2}-2$ & 0.951 & 93 & 0.013 & 0.004 & 0.011 & 0.004 \\
\hline & $C_{\mathrm{T}}$ and $p \mathrm{CO}_{2}-1$ & 0.984 & 31 & 0.006 & 0.004 & 0.004 & \\
\hline & $C_{\mathrm{T}}$ and $p \mathrm{CO}_{2}-2$ & 0.943 & 97 & 0.014 & 0.004 & 0.013 & \\
\hline \multirow[t]{5}{*}{$A_{\mathrm{T}}\left(\mu \mathrm{mol} \mathrm{kg}{ }^{-1}\right)$} & $C_{\mathrm{T}}$ and $\mathrm{pH}_{\mathrm{T}}$ & 0.996 & 218 & 4.4 & -0.2 & 3.1 & \\
\hline & $C_{\mathrm{T}}$ and $p \mathrm{CO}_{2}-1$ & 0.997 & 43 & 4.6 & 2.1 & 3.0 & \\
\hline & $C_{\mathrm{T}}$ and $p \mathrm{CO}_{2}-2$ & 0.991 & 156 & 8.6 & 0.4 & 7.0 & 1.5 \\
\hline & $\mathrm{pH}_{\mathrm{T}}$ and $p \mathrm{CO}_{2-1}$ & 0.802 & 27 & 36.3 & -12.8 & 35.5 & \\
\hline & $\mathrm{pH}_{\mathrm{T}}$ and $p \mathrm{CO}_{2}-2$ & 0.596 & 93 & 75.6 & -423.1 & 72.8 & \\
\hline \multirow[t]{5}{*}{$C_{\mathrm{T}}\left(\mu \mathrm{mol} \mathrm{kg}{ }^{-1}\right)$} & $A_{\mathrm{T}}$ and $\mathrm{pH}_{\mathrm{T}}$ & 0.994 & 218 & 4.0 & 0.2 & 2.4 & \\
\hline & $A_{\mathrm{T}}$ and $p \mathrm{CO}_{2-1}$ & 0.997 & 43 & 3.9 & -1.7 & 2.5 & \\
\hline & $A_{\mathrm{T}}$ and $p \mathrm{CO}_{2}-2$ & 0.989 & 156 & 7.2 & -0.3 & 5.8 & 2.0 \\
\hline & $\mathrm{pH}_{\mathrm{T}}$ and $p \mathrm{CO}_{2}-1$ & 0.680 & 31 & 32.2 & -18.8 & 31.9 & \\
\hline & $\mathrm{pH}_{\mathrm{T}}$ and $p \mathrm{CO}_{2}-2$ & 0.528 & 97 & 69.8 & -21.9 & 63.4 & \\
\hline
\end{tabular}

* These columns have the same units as the first column.

Körtzinger et al. (2000) reported that even after correction of all differences between equilibrator temperature readings and following a time synchronisation procedure, the remaining mean residual in their study was ca. $2 \mu$ atm for most of their cruise. The study by Körtzinger et al. (2000) can be described as an ideal open ocean exercise, with all instruments sharing a common seawater supply, positioned in the same laboratory and sharing common calibration gases. Considering that our cruise took place in coastal waters with strong gradients in temperature, salinity and chemical variables (Körtzinger et al., 1996; Bozec et al., 2005), with the instruments situated in different laboratories and using different calibration gases, and with known water flow problems (Sect. 2.1.1), we conclude that an average difference of $2 \mu \mathrm{atm}$ and an RMSE of $10 \mu \mathrm{atm}$ were good outcomes. The non-ideal conditions of our intercomparison did not negatively affect the overall consistency (we obtained comparable results to the study by Körtzinger et al., 2000). This result is also comparable with a previous (the only other) coastal wa- ter intercomparison described by Körtzinger et al. (1996). In this study, where there was highly variable spatial $p \mathrm{CO}_{2}$ distribution in the southern North Sea, the average difference between observed values was $0.2 \mu$ atm (standard deviation $1.2 \mu \mathrm{atm})$.

There have been a number of intercalibration exercises of $p \mathrm{CO}_{2}$ systems in an indoor seawater pool at the National Institute for Environment Studies, Japan (in 1993, 1998, 2003 and 2009) (Katayama et al., 1999; IOCCP, 2004; Pierrot et al., 2009). Most of the instruments showed good agreement (within $2 \mu \mathrm{atm}$ ).

The MR of the observed $p \mathrm{CO}_{2}-1$ compared with $p \mathrm{CO}_{2}$ calculated from $C_{\mathrm{T}}$ and $A_{\mathrm{T}}$ was $3 \mu \mathrm{atm}(n=43)$, and of $p \mathrm{CO}_{2}-2$, it was $1 \mu \mathrm{atm}(n=156)$, both MR being within the measurement accuracy of the instrument (Table 1). The accuracies of $C_{\mathrm{T}}$ and $A_{\mathrm{T}}$ were $\pm 2.0 \mu \mathrm{mol} \mathrm{kg}^{-1}$ and $\pm 1.5 \mu \mathrm{mol} \mathrm{kg}{ }^{-1}$, respectively, and this translates into a propagated $p \mathrm{CO}_{2}$ uncertainty of $4 \mu \mathrm{atm}$. This is a clear example of where the MR does not provide the whole story, because 

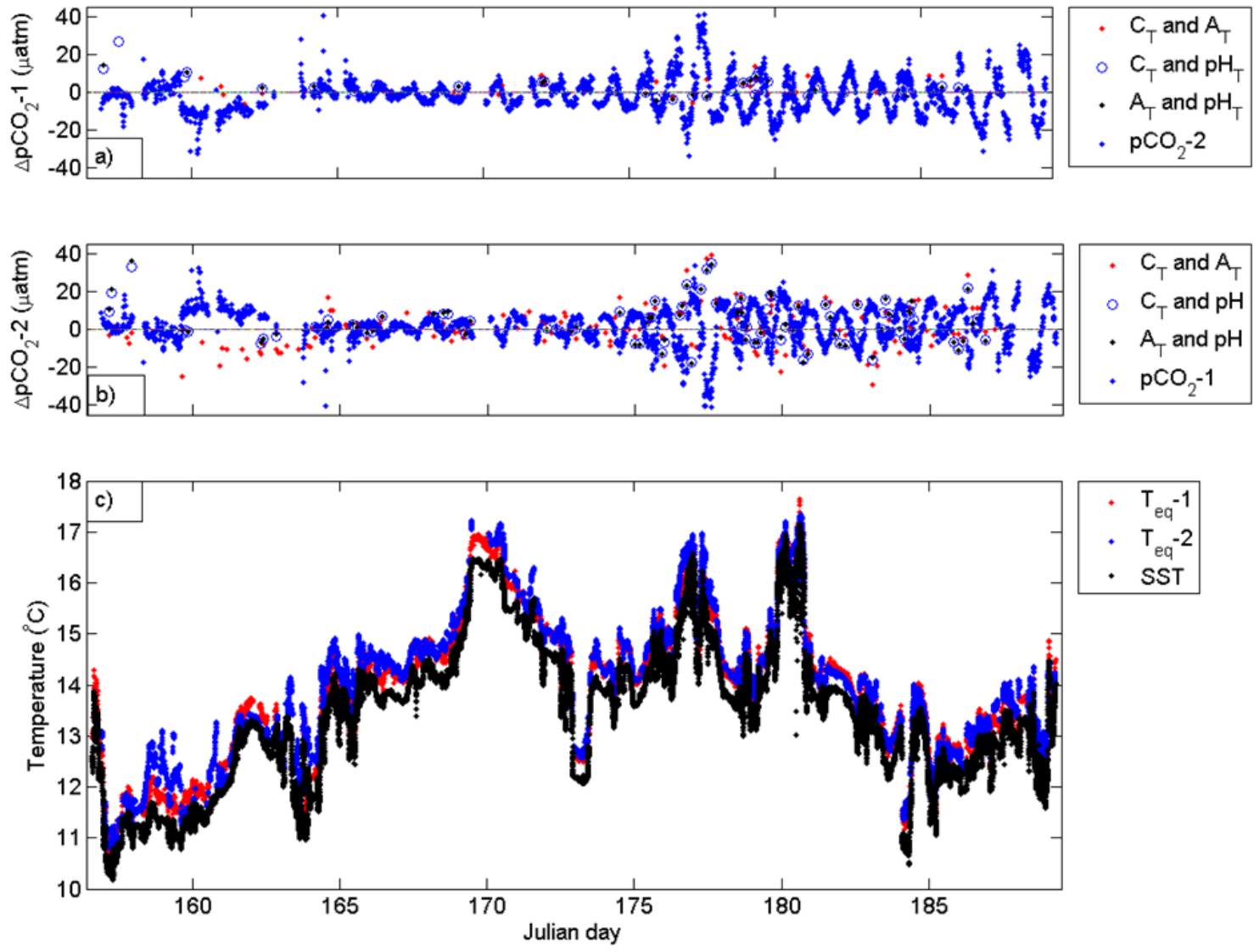

Figure 2. $p \mathrm{CO}_{2}$ residuals of $p \mathrm{CO}_{2}-1$ (a) and $p \mathrm{CO}_{2}-2$ (b) compared to other measured or calculated $p \mathrm{CO}_{2}$ values. Different symbols show different residuals: against $p \mathrm{CO}_{2}$ from $C_{\mathrm{T}}$ and $A_{\mathrm{T}}$ (red plus symbols); against $p \mathrm{CO}_{2}$ from $C_{\mathrm{T}}$ and $\mathrm{pH}_{\mathrm{T}}$ (blue circles); against $p \mathrm{CO}_{2}$ from $A_{\mathrm{T}}$ and $\mathrm{pH}_{\mathrm{T}}$ (blue plus symbols); and against $p \mathrm{CO}_{2}$ from the other measured $p \mathrm{CO}_{2}$ (2 in a and 1 in a, blue dots). (c) In situ temperature, temperature of equilibrator 1 , and temperature of equilibrator 2 .

measured compared with $p \mathrm{CO}_{2}$ calculated from $C_{\mathrm{T}}$ and $A_{\mathrm{T}}$ had a smaller MR, but a higher RMSE and a lower $r$ than $p \mathrm{CO}_{2}-1$ (Table 1). Lower MR does not necessarily mean that there is a better agreement, because positive values may compensate for negative values, as is the case here. The ranges of the residuals were -7 to $14 \mu \mathrm{atm}$ and -29 to $39 \mu \mathrm{atm}$, for $p \mathrm{CO}_{2}-1$ and $p \mathrm{CO}_{2}-2$, respectively. Both of the mean residuals were well within the expected accuracy of $p \mathrm{CO}_{2}$ calculated from $C_{\mathrm{T}}$ and $A_{\mathrm{T}}$ measurements (Millero, 2007). The residuals of the two $p \mathrm{CO}_{2}$ data sets are presented in Fig. 2. A diurnal cycle was observed in the residuals after 8 days of the cruise, with the amplitude increasing over time and reaching a maximum difference between the two $p \mathrm{CO}_{2}$ systems on Julian day 177 (Figs. 2 and 3). The average difference $\left(p \mathrm{CO}_{2}-1\right.$ minus $\left.p \mathrm{CO}_{2}-2\right)$ was $-2 \mu \mathrm{atm}$ and the maximum difference was $41 \mu \mathrm{atm}$.

Temperature forms a critical parameter for $p \mathrm{CO}_{2}$ calculations, with, for example, temperature differences of $2{ }^{\circ} \mathrm{C}$ translating into $p \mathrm{CO}_{2}$ differences of $32 \mu \mathrm{atm}$. The two analytical $p \mathrm{CO}_{2}$ systems were not in the same laboratory, so water spent different lengths of time and took different routes between the ship's seawater intake and the two equilibrators, and therefore warmed differently. This temperature effect was more important when the ship sailed through strong surface water temperature gradients. Rapid changes in seawater temperature of up to $2-3^{\circ} \mathrm{C} \mathrm{min}^{-1}$ were observed on Julian day 180 . However, such rapid temperature changes in the seawater intake may not fully translate into $p \mathrm{CO}_{2}$ changes in the equilibrator, as equilibrator $p \mathrm{CO}_{2}$ is effectively integrated over the equilibration time (around $8 \mathrm{~min}$ for $\mathrm{CO}_{2}$ in both equilibrators). Small differences in the equilibration time between the two systems, i.e. how rapidly they respond to a change in seawater $p \mathrm{CO}_{2}$, may account for some of the observed differences between observations by $p \mathrm{CO}_{2}-1$ and $p \mathrm{CO}_{2}-2$. Moreover, no trend was observed between the difference in measured $p \mathrm{CO}_{2}-1$ and $p \mathrm{CO}_{2}-2$ versus the difference between the temperature in equilibrator 1 and the sea surface temperature, whereas a positive relationship was observed for equilibrator 2 (Fig. 4). The discrepancy between the two $p \mathrm{CO}_{2}$ systems was negative at low light levels (at night, $p \mathrm{CO}_{2}-1$ was smaller than $p \mathrm{CO}_{2}$-2) and positive during daylight hours $\left(p \mathrm{CO}_{2}-1\right.$ larger than $\left.p \mathrm{CO}_{2}-2\right)$ (Fig. 3). 

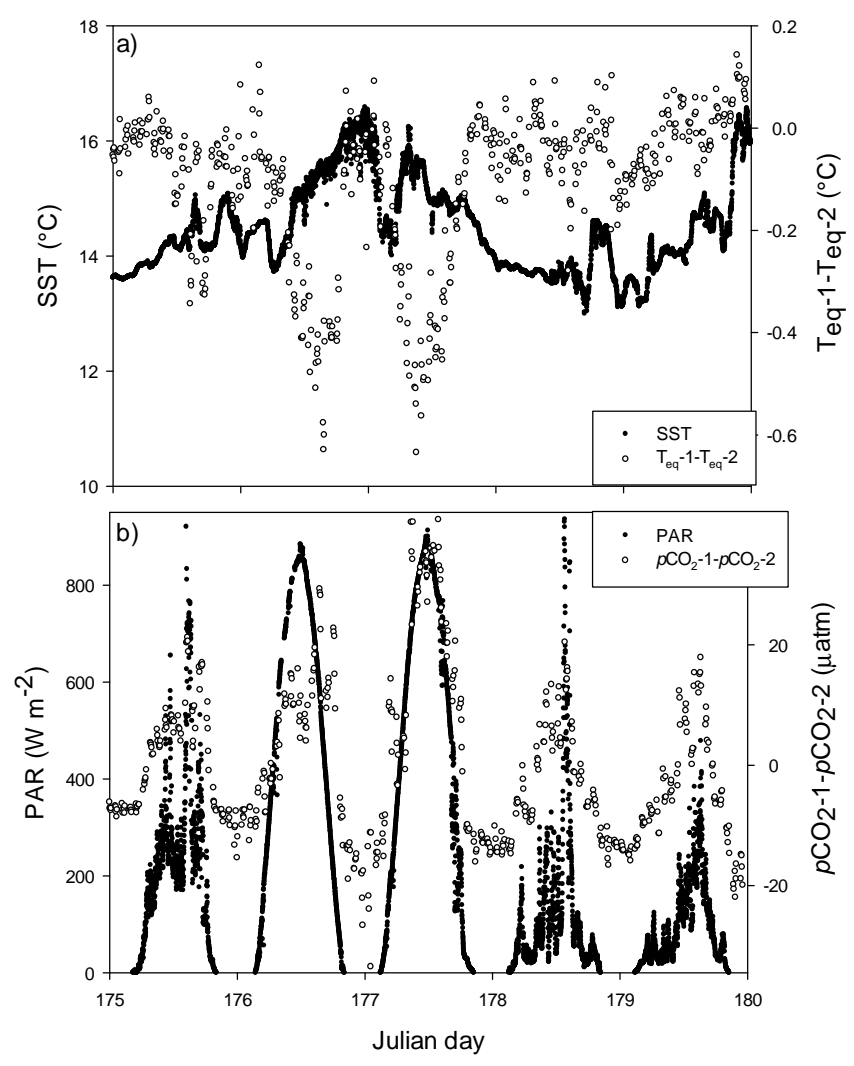

Figure 3. Comparison between (a) the in situ sea surface temperature (SST $\left({ }^{\circ} \mathrm{C}\right)$, in black circles) and the difference in temperatures inside the equilibrators of instruments 1 and $2\left({ }^{\circ} \mathrm{C}\right.$, in white circles), and (b) the phototosynthetically active radiance (PAR $\left(\mathrm{W} \mathrm{m}^{-2}\right)$, in black circles) and the $p \mathrm{CO}_{2}$ difference between instruments 1 and 2 ( $\mu \mathrm{atm}$, in white circles) measured over five days.

This pattern is consistent with respiration at night and photosynthesis during the day in the seawater supply to the $p \mathrm{CO}_{2}$ 2 equilibrator or in the equilibrator itself. The length of the seawater pipes to equilibrator 2 was about twice as long as to equilibrator 1. Furthermore, the equilibrator of $p \mathrm{CO}_{2}-2$ was subject to direct daylight compared with the $p \mathrm{CO}_{2}-1$ equilibrator, which was shielded from light. A multiple regression analysis was performed to estimate the relative importance of two factors (the temperature difference between the two equilibrators $\left(\Delta T_{\mathrm{eq}}\right)$, and PAR) in determining the size of the $p \mathrm{CO}_{2}$ differences $\left(\Delta p \mathrm{CO}_{2}=p \mathrm{CO}_{2}-1-p \mathrm{CO}_{2}-2\right)$. A correlation coefficient of 0.47 between the predictor variables $\left(\Delta T_{\text {eq }}\right.$ and PAR) indicated that they are not strongly correlated. The tolerance (or the inverse of the variance inflation factor) is 0.78 , indicating no colinearity problems, as this value is well above the tolerance threshold of 0.1 (Quinn and Keough, 2002). The analysis indicated that the correlation of $\Delta p \mathrm{CO}_{2}$ with $\Delta T_{\mathrm{eq}}$ and PAR was statistically significant $(p<0.0001 ; F=587.6)$ and that the two parameters together explained $38 \%$ of the $\Delta p \mathrm{CO}_{2}$ variance. $\Delta T_{\mathrm{eq}}$ and PAR were found individually to explain 17 and $18 \%$, respectively, of the variance in $\Delta p \mathrm{CO}_{2}$. We thus conclude that the diurnal pattern in the $p \mathrm{CO}_{2}$ differences between the two instruments was caused by a combination of (a) biological activity in the seawater system or in equilibrator 2 , and (b) variations in water flow and temperature perturbations in $p \mathrm{CO}_{2}$-2 (Sect. 2.1.1). The first issue should be addressed in future studies by protection of seawater tubing and equilibrators from light, and by regular cleaning of the seawater intake and equilibrators. In addition, the flow rate of the ship's seawater supply should be kept constant, while the water flow to equilibrators should be sufficiently large and should be kept constant by using a water flow controller. Furthermore, the temperature measurements inside the equilibrator need to be accurate, in agreement with Körtzinger et al. (2000), and as implemented in the Surface Ocean $\mathrm{CO}_{2}$ Atlas (SOCAT), by making an accuracy of $0.05^{\circ} \mathrm{C}$ for the equilibrator temperature a pre-requisite for data set quality flags $\mathrm{A}$ and $\mathrm{B}$ (Pfeil et al., 2013; Bakker et al., 2014). The maximum $p \mathrm{CO}_{2}$ discrepancies observed in our study (up to $20 \mu \mathrm{atm}$ ) are larger than the $5 \mu \mathrm{atm}$ criterion for cross-over discrepancies in order to achieve flag A status (the highest quality) in the new SOCAT version 3 (Wanninkhof et al., 2013), further emphasising the desirability of following the recommendation of this paper.

\subsection{Intercomparison of measured and calculated variables}

The results of the intercomparison between observed carbonate chemistry variables and those calculated from different pairs of measured variables are presented in Table 1. Statistical techniques were used to evaluate the agreement between the observed and calculated values. The comparison between observed $\mathrm{pH}_{\mathrm{T}}$ and $\mathrm{pH}_{\mathrm{T}}$ calculated from observed $C_{\mathrm{T}}$ and $A_{\mathrm{T}}$ showed a mean residual of $0.001 \mathrm{pH}_{\mathrm{T}}$ units and an RMSE of $0.008 \mathrm{pH}_{\mathrm{T}}$ units (Table 1). This was compared with the 0.004 $\mathrm{pH}_{\mathrm{T}}$ unit accuracy of the measurements. The linear correlation coefficient $(r)$ between observed and calculated values was $0.952 . \mathrm{pH}_{\mathrm{T}}$ calculated from $C_{\mathrm{T}}$ and $A_{\mathrm{T}}$ had an uncertainty of $0.005 \mathrm{pH}_{\mathrm{T}}$ units. The RMSE corresponded to twice the accuracy of the $\mathrm{pH}_{\mathrm{T}}$ measurements, and slightly less than twice the uncertainty expected from the calculation, so we conclude that there was good agreement between calculated and measured $\mathrm{pH}_{\mathrm{T}}$.

The value of $\mathrm{pH}_{\mathrm{T}}$ calculated from $p \mathrm{CO}_{2}-1$ and $A_{\mathrm{T}}$ had an RMSE of 0.006 when compared to the measured $\mathrm{pH}_{\mathrm{T}}$, and the same calculation with $p \mathrm{CO}_{2}-2$ led to an RMSE of 0.013 (Table 1). The calculated values of $\mathrm{pH}_{\mathrm{T}}$ using $p \mathrm{CO}_{2}-1$ and $A_{\mathrm{T}}$ were therefore better (lower RMSE) than $\mathrm{pH}_{\mathrm{T}}$ calculated from $C_{\mathrm{T}}$ and $A_{\mathrm{T}}$, whereas the calculations using $p \mathrm{CO}_{2}-2$ and $A_{\mathrm{T}}$ had a higher RMSE. Calculations of $\mathrm{pH}_{\mathrm{T}}$ from the combination of $p \mathrm{CO}_{2}$ with either $C_{\mathrm{T}}$ or $A_{\mathrm{T}}$ may be expected to yield more accurate estimates than calculations of $\mathrm{pH}_{\mathrm{T}}$ from $C_{\mathrm{T}}$ and $A_{\mathrm{T}}$ (Table 1), because they do not require reliable estimates of the second dissociation constant of carbonic acid and are relatively insensitive to uncertainties in 

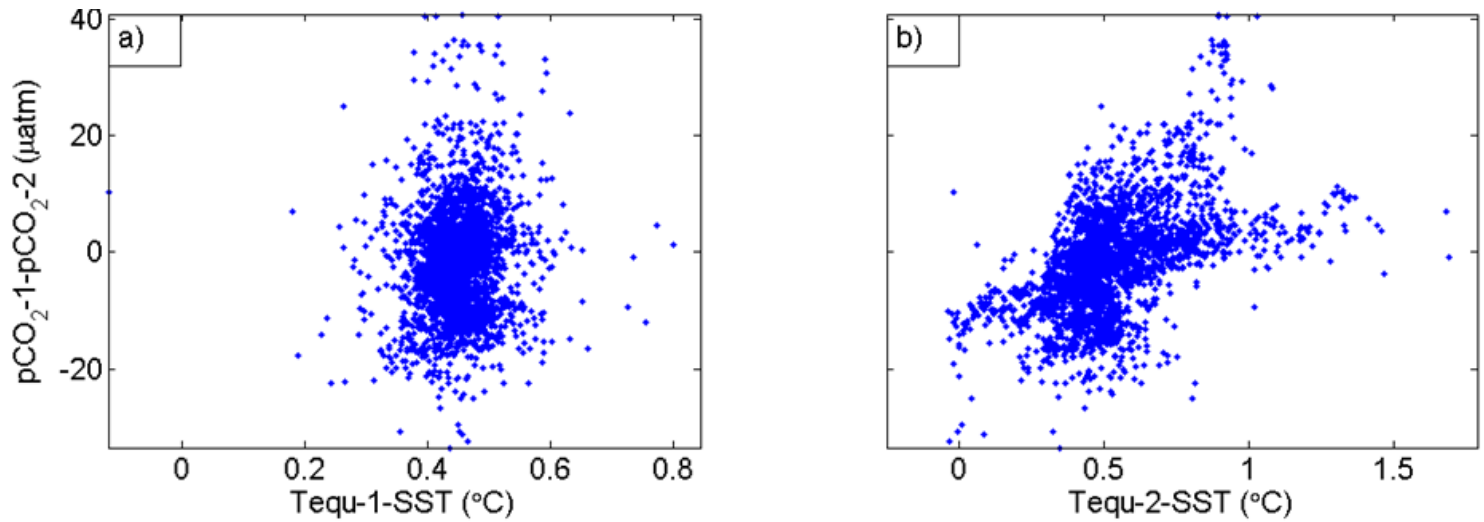

Figure 4. Difference between the two $\mathrm{pCO}_{2}$ data sets and (a) the difference between the temperature inside equilibrator 1 and sea surface temperature, and (b) the difference between the temperature inside equilibrator 2 and sea surface temperature.

$C_{\mathrm{T}}$ and $A_{\mathrm{T}}$ (Millero, 2007). However, this is not always the case, as shown here.

$p \mathrm{CO}_{2}$ calculated from $C_{\mathrm{T}}$ and $A_{\mathrm{T}}$ compared to the $p \mathrm{CO}_{2}-$ 1 and $p \mathrm{CO}_{2}-2$ observational data sets showed RMSE values of $6 \mu \mathrm{atm}$ and $12 \mu \mathrm{atm}$, and mean residuals of $3 \mu \mathrm{atm}$ and $1 \mu \mathrm{atm}$ (Table 1). This compares to accuracies associated with direct measurement of $p \mathrm{CO}_{2}$ of $4 \mu \mathrm{atm}$ for $p \mathrm{CO}_{2}-1$ and $10 \mu$ atm for $p \mathrm{CO}_{2}-2 . p \mathrm{CO}_{2}$ calculated from $C_{\mathrm{T}}$ and $A_{\mathrm{T}}$ is predicted to have an uncertainty of $4 \mu \mathrm{atm}$. We therefore conclude that our calculated data set is in good agreement with the measured data set.

Lueker et al. (2000) carried out a similar field-based intercomparison with comparable measurement quality and overall uncertainty. At lower $f \mathrm{CO}_{2}$, Lueker et al.'s (2000) differences between calculated and measured $f \mathrm{CO}_{2}$ were slightly lower than in our study, but at high $f \mathrm{CO}_{2}$ they obtained slightly higher differences. Lueker et al. (2000) reported that the mean relative difference between measured $f \mathrm{CO}_{2}$ and $f \mathrm{CO}_{2}$ calculated from $C_{\mathrm{T}}$ and $A_{\mathrm{T}}$ (for $f \mathrm{CO}_{2}$ less than $500 \mu \mathrm{atm}$ ) was $0.07 \%$ (standard deviation $0.50 \%$ ). For $f \mathrm{CO}_{2}$ above $500 \mu \mathrm{atm}$, there was a mean relative difference of $3.3 \%$ (standard deviation $1.2 \%$ ). For example, for $f \mathrm{CO}_{2}$ of $500 \mu \mathrm{atm}$, this corresponds to a difference of $16.5 \mu \mathrm{atm}$ and a standard deviation of $6.0 \mu \mathrm{atm} . p \mathrm{CO}_{2}$ and $\mathrm{pH}_{\mathrm{T}}$ do not make a good pair for predicting other variables, because $\mathrm{CO}_{2}$ and hydrogen ion concentrations are smaller than carbonate and bicarbonate concentrations. Therefore, relatively small errors in $\mathrm{CO}_{2}$ and/or hydrogen ions propagate into relatively large errors in carbonate and bicarbonate concentrations, when the system is computed from $p \mathrm{CO}_{2}$ and $\mathrm{pH}_{\mathrm{T}}$. This is also indicated by our data, where the mean residuals for $A_{\mathrm{T}}$ and $C_{\mathrm{T}}$ (observed minus calculated) are comparable to the calculated uncertainties, but are both one order of magnitude greater from $p \mathrm{CO}_{2}$ and $\mathrm{pH}_{\mathrm{T}}$ than the accuracy and precision of observations (Table 1).

$C_{\mathrm{T}}$ calculated from $A_{\mathrm{T}}$ and $p \mathrm{CO}_{2}$ had RMSE values of 3.9 and $7.2 \mu \mathrm{mol} \mathrm{kg}^{-1}$ compared to the measurement data sets of systems $p \mathrm{CO}_{2}-1$ and $p \mathrm{CO}_{2}-2$, and mean residuals of -1.7 and $-0.3 \mu \mathrm{mol} \mathrm{kg}-1$ (Table 1). This compares to an accuracy associated with direct measurement of $C_{\mathrm{T}}$ of $2 \mu \mathrm{mol} \mathrm{kg}{ }^{-1}$. $A_{\mathrm{T}}$ calculated from $C_{\mathrm{T}}$ and $p \mathrm{CO}_{2}-1$ had an MR of $2.1 \mu \mathrm{mol} \mathrm{kg}{ }^{-1}$ and an RMSE value of $4.6 \mu \mathrm{mol} \mathrm{kg}^{-1}$, and the calculated uncertainty was $3 \mu \mathrm{mol} \mathrm{kg}{ }^{-1}$ (Table 1). This compares to an accuracy associated with direct measurement of $A_{\mathrm{T}}$ of $1.5 \mu \mathrm{mol} \mathrm{kg}^{-1}$.

Several papers have raised the issue of the impact of organic acids on computations of the $\mathrm{CO}_{2}$ system in coastal waters (Kim et al., 2006; Hernández-Ayón et al., 2007; Kim and Lee, 2009). Dissolved organic matter (DOM) produced by phytoplankton during photosynthesis potentially makes a significant contribution to seawater total alkalinity, the magnitude of which has been reported to vary depending on the phytoplankton species (Kim and Lee, 2009). Dissolved organic matter in this context acts as an additional acid-base pair in seawater. Analytically, this would interfere with our determination of $A_{\mathrm{T}}$ (by $\mathrm{HCl}$ titration). We can therefore compare measured $A_{\mathrm{T}}$ values to the respective calculated values from, for example, $C_{\mathrm{T}}$ and $\mathrm{pH}_{\mathrm{T}}$. As shown in Fig. 5, there is only a weak correlation $\left(r^{2}=0.06\right)$ between dissolved organic carbon (DOC) and $A_{\mathrm{T}}$ discrepancy, of the sign we should expect if DOM was affecting $A_{\mathrm{T}}$ but was not statistically significant. Similar results were also obtained in an upwelling environment (Loucaides et al., 2012). Therefore, we found no evidence of a significant contribution to seawater total alkalinity from DOM. During three days in the same coccolithophore bloom, we collected additional samples of filtered $C_{\mathrm{T}}$ and $A_{\mathrm{T}}$ from the underway seawater supply. The filtering was carried out using an in-line filter (Sartorius Sartobran 300 sterile capsule, $0.45 \mu \mathrm{m}$ pore size). In this way, we studied the effects of the presence of calcite mineral particles in the surface waters on $C_{\mathrm{T}}$ and $A_{\mathrm{T}}$ measurements. The average differences between unfiltered and filtered samples were 2.4 and $3.7 \mu \mathrm{mol} \mathrm{kg}^{-1}$ for $C_{\mathrm{T}}$ and $A_{\mathrm{T}}$, respectively, with values in the unfiltered samples being higher. 


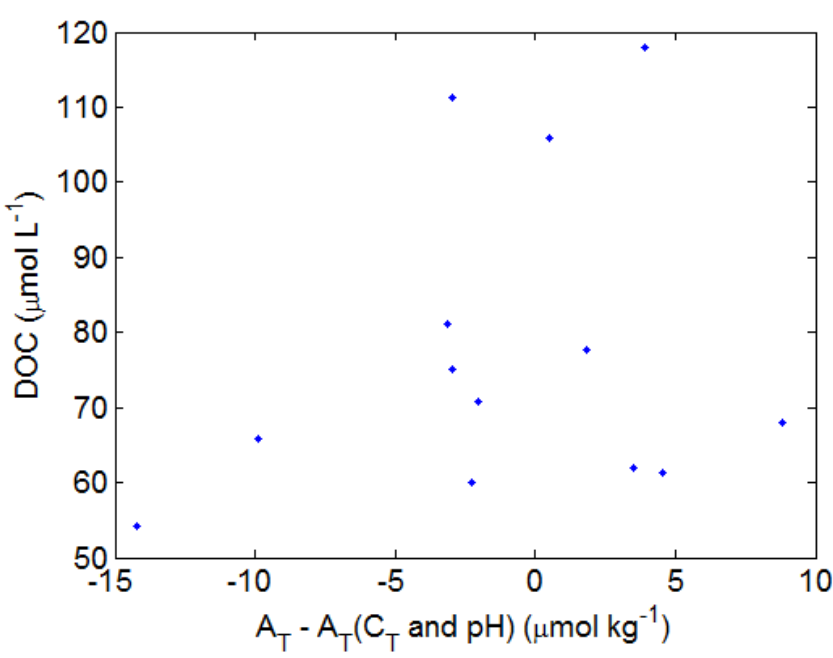

Figure 5. Dissolved organic carbon (DOC) and total alkalinity $\left(A_{\mathrm{T}}\right)$ discrepancy (measured $A_{\mathrm{T}}$ minus calculated $A_{\mathrm{T}}$ from $C_{\mathrm{T}}$ and $\mathrm{pH}_{\mathrm{T}}$ ).

The differences between replicates of filtered samples were on average higher than those of unfiltered samples. The differences between measured $\mathrm{pH}_{\mathrm{T}}$ and $\mathrm{pH}_{\mathrm{T}}$ calculated from filtered and unfiltered $C_{\mathrm{T}}$ and $A_{\mathrm{T}}$ were -0.003 and 0.005 , respectively. The difference between measured $p \mathrm{CO}_{2}-1$ and $p \mathrm{CO}_{2}-2$ and $p \mathrm{CO}_{2}$ calculated from filtered and unfiltered $C_{\mathrm{T}}$ and $A_{\mathrm{T}}$ was $-4 \mu \mathrm{atm}$ in both cases. An influence of dissolution of calcite particles on $C_{\mathrm{T}}$ and $A_{\mathrm{T}}$ measurements would be expected to lead to $C_{\mathrm{T}}$ and $A_{\mathrm{T}}$, with discrepancies twice as large for $A_{\mathrm{T}}$ as for $C_{\mathrm{T}}$. This ratio was however not exactly observed in our study, and hence it is unclear from our observations whether dissolution of $\mathrm{CaCO}_{3}$ particles affected $C_{\mathrm{T}}$ and $A_{\mathrm{T}}$ measurements. Filtration of samples for $C_{\mathrm{T}}$ potentially introduces a further error through $\mathrm{CO}_{2}$ loss by turbulence and ebullition, which can affect the $C_{\mathrm{T}}$ measurement, although we took precautions to avoid bubbles in the filter.

So far in this paper, we have checked the consistency of the carbonate system and assessed the quality of the carbonate system measurements. Overall, the sizes of the offsets between measured and calculated values agreed well with expectations based on theoretical calculations and expected accuracies of measurements. Four out of the five independent data sets of carbonate chemistry variables are deemed to be of high quality and therefore suitable to be used as a basis for evaluations of the impacts of ocean acidification by other scientists on the same cruise; see, for instance, the papers by Poulton et al. (2014) and Young et al. (2014).

Next, we examine possible reasons for discrepancies observed during the $p \mathrm{CO}_{2}$ measurements using $p \mathrm{CO}_{2}-2$ (points 1 to 3 below), and make "good practice" recommendations from an investigation of the remaining discrepancies (points 4 and 5 below). Some of these recommendations are new and some are not, but we think it is good to compile them all.
1. The duration of seawater transit in the ship's underway system from the seawater intake to the point of sample collection or measurement ( 1 to $3 \mathrm{~min}$ ) varied between the carbonate chemistry measurements. It is important to recognise the period of time it takes for the seawater to arrive in the equilibrator of a $p \mathrm{CO}_{2}$ instrument. This will allow correction for the difference between the intake temperature and the equilibrator temperature. This has already been emphasised by Dickson et al. (2007). The omission of a time correction results in unrealistic spikes in the difference between seawater temperature and the temperature inside the equilibrator. Appropriate temperature correction will reduce artificial variability in $p \mathrm{CO}_{2}$, even though the average $p \mathrm{CO}_{2}$ value is still likely to be correct. In addition, both the underway seawater system and the equilibrators tend to smooth out short-lived signals in temperature and $p \mathrm{CO}_{2}$, because of the time the water spent travelling along the underway water supply and inside the equilibrator. These delay times can affect the measurement reliability by smoothing out strong gradients. These effects are particularly important in regions with rapid changes in carbonate chemistry and sea water temperature, for example in shelf sea regions with freshwater inputs, in continental shelf break regions with enhanced vertical mixing (internal tides or upwelling), and in regions with sea ice melt. The effects of strong gradients on $p \mathrm{CO}_{2}$ have been noted by Körtzinger et al. (1996) and Körtzinger et al. (2000).

2. To obtain high-quality $p \mathrm{CO}_{2}$ data sets, we recommend that special care be taken with the operation of the equilibrator systems, including (a) careful control of the seawater supply and the water flow through the equilibrator (Körtzinger et al., 1996), (b) accurate temperature readings (Körtzinger et al., 2000; Pierrot et al., 2009; Bakker et al., 2014), and (c) prevention of phototrophic growth in the equilibrator by complete shielding from light, although non-phototrophic microbial growth will not be prevented. It should be noted that shading of the equilibrator will not stop respiration in the pipes or equilibrator. The latter can be calculated assuming a residence time of $12 \mathrm{~min}$ ( $2 \mathrm{~min}$ in the ship's pipe network and $10 \mathrm{~min}$ in the equilibrator), community respiration of $54 \mu \mathrm{mol} \mathrm{L}^{-1} \mathrm{~d}^{-1}$ in shelf sea waters (highest rate in Holligan et al., 1984), and a respiratory quotient of 1 . This "worst case" scenario results in the production of $0.4 \mu \mathrm{mol} \mathrm{L}^{-1} C_{\mathrm{T}}$, which equates to $0.75 \mu \mathrm{atm} p \mathrm{CO}_{2}$, using the average $A_{\mathrm{T}}, C_{\mathrm{T}}, \mathrm{SST}$, salinity, silicate and phosphate concentrations from D366 (calculated using CO2SYS). This value is clearly within the uncertainty of our measurements. Nevertheless, regular cleaning of the equilibrator and pipe network, where possible, is recommended in order to prevent the build-up of microbial mats and associated respiration. 
3. When comparing a pair of variables, it is important to examine the residuals as a function of time as well as to construct a scatter plot of one variable against the other. For example, from examination of Fig. 1 alone we would not have identified the diurnal variation between the two $p \mathrm{CO}_{2}$ systems (Fig. 2).

4. Differences between the recorded sampling time and the actual sampling time also need to be taken into account. $C_{\mathrm{T}}$ and $A_{\mathrm{T}}$ are discrete measurements, while $p \mathrm{CO}_{2}$ and $\mathrm{pH}_{\mathrm{T}}$ are near-continuous measurements. In addition to the transit times between the intake and the instrument, $p \mathrm{CO}_{2}$ is an integrated measurement over the timescale of equilibration (around $8 \mathrm{~min}$ ), and $\mathrm{pH}_{\mathrm{T}}$ is an integrated measurement over the timescale of filling the sample chamber (ca. $60 \mathrm{~s}$ ). When comparing carbonate chemistry data sets, corrections should be made for the asynchronous times of sample collection for the different variables.

5. Characterisation of the extinction coefficients of each batch of $\mathrm{pH}$ indicator dye on the instrument used for ship-board $\mathrm{pH}$ analysis is recommended, rather than using published values (Clayton and Byrne, 1993; Zhang and Byrne, 1996; Hopkins et al., 2000; Mosley et al., 2004; Gabriel et al., 2005; Liu et al., 2011). This is particularly important where the indicator has not been purified (Yao et al., 2007), and where the detection system has a wider optical bandwidth than that used in the literature to characterise the indicator (here the optical bandwidth used for our $\mathrm{pH}$ system is $15-20 \mathrm{~nm}$; Rérolle et al., 2013). The discrepancy between $\mathrm{pH}_{\mathrm{T}}$ values calculated with our coefficients and values calculated with coefficients from Zhang and Byrne (1996) was about $0.02 \mathrm{pH}_{\mathrm{T}}$ units (Rérolle et al., 2013). Rérolle et al. (2013) estimated that about $0.005 \mathrm{pH}_{\mathrm{T}}$ units of the observed discrepancy were due to impurities in the indicator, and that about $0.015 \mathrm{pH}_{\mathrm{T}}$ units were due to the wider bandpass detection window in our ship-board $\mathrm{pH}$ system. This recommendation has been made before by Liu et al. (2011) and Yao et al. (2007).

\subsection{Ratio of total boron to salinity and carbonate constants}

The calculations of the carbonate chemistry variables were undertaken for a second time using another ratio of total boron to salinity (Lee et al., 2010) for the combinations of pairs involving $A_{\mathrm{T}}$ (because the ratio of total boron to salinity only influences calculations involving $A_{\mathrm{T}}$ ). We then compared the results obtained against those using the original ratio of total boron to salinity from Uppström (1974). Statistically significant differences (ANOVA, $p$ values $<0.001$ ) were seen for both $p \mathrm{CO}_{2}$ and $\mathrm{pH}_{\mathrm{T}}$ calculated from $C_{\mathrm{T}}$ and $A_{\mathrm{T}}$ using the different ratios of total boron to salinity. There were also significant differences between $C_{\mathrm{T}}$ values calculated from $A_{\mathrm{T}}$ and $\mathrm{pH}_{\mathrm{T}}$ and from $A_{\mathrm{T}}$ and $p \mathrm{CO}_{2}-2$ using the different constants, and $A_{\mathrm{T}}$ calculated from both $C_{\mathrm{T}}$ and $\mathrm{pH}_{\mathrm{T}}$ and $C_{\mathrm{T}}$ and $p \mathrm{CO}_{2}-2$. There were, however, no statistically significant differences when calculating $\mathrm{pH}_{\mathrm{T}}$ from $p \mathrm{CO}_{2}-1$ or $p \mathrm{CO}_{2}-2$ and $A_{\mathrm{T}}$, or $p \mathrm{CO}_{2}-1$ and $p \mathrm{CO}_{2}-2$ calculated from $\mathrm{pH}_{\mathrm{T}}$ and $A_{\mathrm{T}}$ (Fig. 6 and Table 2). This was because the calculation of $\mathrm{pH}_{\mathrm{T}}$ from $p \mathrm{CO}_{2}$ and $A_{\mathrm{T}}$ is mainly driven by $p \mathrm{CO}_{2}$ and not by $A_{\mathrm{T}}$ (and the same when calculated $p \mathrm{CO}_{2}$ from $\mathrm{pH}_{\mathrm{T}}$ and $A_{\mathrm{T}}$ ). The residuals were on the whole smaller when using the ratio of total boron to salinity from Uppström (1974) compared to using Lee et al. (2010) (Fig. 6). The differences between mean residuals were $5 \mu \mathrm{atm}, 0.007$ $\mathrm{pH}_{\mathrm{T}}$ units, $2.9 \mu \mathrm{mol} \mathrm{kg}{ }^{-1}$ and $3.2 \mu \mathrm{mol} \mathrm{kg}{ }^{-1}$ for $p \mathrm{CO}_{2}, \mathrm{pH}_{\mathrm{T}}$, $C_{\mathrm{T}}$ and $A_{\mathrm{T}}$, respectively when subtracting results obtained using the constants from Uppström (1974) from those obtained using the constants from Lee et al. (2010). These discrepancies might not be so significant in an ocean acidification context, but they are substantial in terms of air-sea flux calculations in coastal waters. Overall, for our ranges of temperature and salinity, Uppström (1974) gave the best results when compared to observed values for carbonate chemistry variables.

The calculations of the carbonate chemistry variables were undertaken for a third time using other sets of carbonate constants (Roy et al., 1993; Lueker et al., 2000; Millero et al., 2006). We then compared the results obtained against those using the original carbonate constants, from Mehrbach and the total boron-to-salinity ratio of Uppström (1974). We omitted the $\mathrm{pH}_{\mathrm{T}}-p \mathrm{CO}_{2}$ pair from consideration because they are not a good pair for the calculations.

Statistically significant differences (ANOVA, $p$ values $<0.001$ ) were noted when using the Roy et al. (1993) constants (hereinafter Roy) to calculate $p \mathrm{CO}_{2}-1$ and $p \mathrm{CO}_{2}$ 2 from $C_{\mathrm{T}}$ and $A_{\mathrm{T}}, C_{\mathrm{T}}$ or $\mathrm{pH}_{\mathrm{T}}$, or $A_{\mathrm{T}}$ and $\mathrm{pH}_{\mathrm{T}}$. The use of Lueker et al.'s (2000) constants (hereinafter Lueker) produces results that do not yield statistically significant differences from Mehrbach when calculating $p \mathrm{CO}_{2}-1$ and $p \mathrm{CO}_{2}$ 2 from $C_{\mathrm{T}}$ and $A_{\mathrm{T}}, C_{\mathrm{T}}$ or $\mathrm{pH}_{\mathrm{T}}$, or $A_{\mathrm{T}}$ and $\mathrm{pH}_{\mathrm{T}}$. The use of Millero et al.'s (2006) constant (hereinafter Millero) did not yield statistically significant differences from Mehrbach when calculating $p \mathrm{CO}_{2}-2$ from $C_{\mathrm{T}}$ and $A_{\mathrm{T}}, C_{\mathrm{T}}$ or $\mathrm{pH}_{\mathrm{T}}$, or $A_{\mathrm{T}}$ and $\mathrm{pH}_{\mathrm{T}}$. The maximum mean residuals were always observed when using Roy's constants (up to $23 \mu \mathrm{atm}$ when calculating $p \mathrm{CO}_{2}-2$ from $C_{\mathrm{T}}$ and $A_{\mathrm{T}}$ ) (Table 3 ). The calculated $p \mathrm{CO}_{2}$ values using the constants of Roy were significantly higher than those by Mehrbach in other studies (Wanninkhof et al., 1999). McElligott et al. (1998) showed a good agreement between measured $p \mathrm{CO}_{2}$ and $p \mathrm{CO}_{2}$ calculated from $C_{\mathrm{T}}$ and $A_{\mathrm{T}}$ using Mehrbach at the sea surface.

There were no significant differences when calculating $\mathrm{pH}_{\mathrm{T}}$ from $p \mathrm{CO}_{2}-1$ and either $C_{\mathrm{T}}$ or $A_{\mathrm{T}}$. However, there were statistically significant differences when using Roy to calculate $\mathrm{pH}_{\mathrm{T}}$ from $p \mathrm{CO}_{2}-2$ and $C_{\mathrm{T}}$ or $A_{\mathrm{T}}$. Of particular importance, the mean residual is significantly higher when 
Table 2. Directly measured $\mathrm{pH}_{\mathrm{T}}$, partial pressure of $\mathrm{CO}_{2}\left(p \mathrm{CO}_{2}-1\right)$, dissolved inorganic carbon $\left(C_{\mathrm{T}}\right)$ and total alkalinity $\left(A_{\mathrm{T}}\right)$ are compared to values calculated for the combinations of pairs involving $A_{\mathrm{T}}$ using different ratios of total boron to salinity. RMSE is root mean square error and MR is mean of the residuals. The two different ratios of total boron to salinity are from Lee et al. (2010) and Uppström (1974). The carbonate constants are from Mehrbach et al. (1973), refitted by Dickson and Millero (1987).

\begin{tabular}{llrrrr}
\hline & Ratio of total boron to salinity & \multicolumn{2}{c}{ Lee } & \multicolumn{2}{c}{ Uppström } \\
\hline Measured variable & Calculated variable from & RMSE* & MR* & RMSE* & MR \\
\hline$p \mathrm{CO}_{2}-1(\mu \mathrm{atm})$ & $A_{\mathrm{T}}$ and $\mathrm{pH}_{\mathrm{T}}$ & 5 & 1 & 6 & 2 \\
& $C_{\mathrm{T}}$ and $A_{\mathrm{T}}$ & 10 & 8 & 6 & 3 \\
\hline$p \mathrm{CO}_{2}-2(\mu \mathrm{atm})$ & $A_{\mathrm{T}}$ and $\mathrm{pH}_{\mathrm{T}}$ & 11 & 3 & 11 & 4 \\
& $C_{\mathrm{T}}$ and $A_{\mathrm{T}}$ & 14 & 6 & 12 & 1 \\
\hline \multirow{3}{*}{$\mathrm{pH}_{\mathrm{T}}$} & $C_{\mathrm{T}}$ and $A_{\mathrm{T}}$ & 0.012 & -0.005 & 0.008 & 0.001 \\
& $A_{\mathrm{T}}$ and $p \mathrm{CO}_{2}-1$ & 0.006 & 0.002 & 0.006 & 0.002 \\
& $A_{\mathrm{T}}$ and $p \mathrm{CO}_{2}-2$ & 0.013 & 0.003 & 0.013 & 0.004 \\
\hline \multirow{2}{*}{$A_{\mathrm{T}}\left(\mu \mathrm{mol} \mathrm{kg}{ }^{-1}\right)$} & $C_{\mathrm{T}}$ and $\mathrm{pH}_{\mathrm{T}}$ & 6.6 & 2.9 & 4.4 & -0.2 \\
& $C_{\mathrm{T}}$ and $p \mathrm{CO}_{2}-1$ & 7.3 & 5.3 & 4.6 & 2.1 \\
& $C_{\mathrm{T}}$ and $p \mathrm{CO}_{2}-2$ & 10.7 & 3.6 & 8.6 & 0.4 \\
\hline$C_{\mathrm{T}}\left(\mu \mathrm{mol} \mathrm{kg} \mathrm{kg}^{-1}\right)$ & $A_{\mathrm{T}}$ and $\mathrm{pH}_{\mathrm{T}}$ & 6.1 & -2.7 & 4.0 & 0.2 \\
& $A_{\mathrm{T}}$ and $p \mathrm{CO}_{2}-1$ & 6.1 & -4.4 & 3.9 & -1.7 \\
& $A_{\mathrm{T}}$ and $p \mathrm{CO}_{2}-2$ & 8.9 & -3.0 & 7.2 & -0.3 \\
\hline
\end{tabular}

* These columns have the same units as the first column.

Table 3. Comparison of directly measured $\mathrm{pH}_{\mathrm{T}}$, partial pressure of $\mathrm{CO}_{2}\left(p \mathrm{CO}_{2}\right)$, dissolved inorganic carbon $\left(C_{\mathrm{T}}\right)$ and total alkalinity $\left(A_{\mathrm{T}}\right)$ to values calculated using different carbonate constants. RMSE is root mean square error and MR is mean of the residuals. The two different carbonate constants are from Roy et al. (1993), Millero et al. (2006), and Mehrbach et al. (1973), refitted by Dickson and Millero (1987) and Lueker et al. (2000). The ratio of total boron to salinity is from Uppström (1974).

\begin{tabular}{|c|c|c|c|c|c|c|c|c|c|}
\hline \multirow[b]{2}{*}{ Measured variable } & \multirow{2}{*}{$\begin{array}{l}\text { Carbonate constants } \\
\text { Calculated variable from }\end{array}$} & \multicolumn{2}{|c|}{ Mehrbach } & \multicolumn{2}{|c|}{ Roy } & \multicolumn{2}{|c|}{ Millero } & \multicolumn{2}{|c|}{ Lueker } \\
\hline & & RMSE* & $\mathrm{MR}^{*}$ & RMSE* & $\mathrm{MR}^{*}$ & RMSE* & $\mathrm{MR}^{*}$ & RMSE* & $\mathrm{MR}^{*}$ \\
\hline \multirow[t]{3}{*}{$p \mathrm{CO}_{2-1}(\mu \mathrm{atm})$} & $C_{\mathrm{T}}$ and $\mathrm{pH}_{\mathrm{T}}$ & 5 & 3 & 10 & 11 & 8 & 8 & 6 & 4 \\
\hline & $A_{\mathrm{T}}$ and $\mathrm{pH}_{\mathrm{T}}$ & 6 & 2 & 9 & 8 & 8 & 7 & 6 & 3 \\
\hline & $C_{\mathrm{T}}$ and $A_{\mathrm{T}}$ & 6 & 3 & 26 & 25 & 8 & 5 & 6 & 3 \\
\hline \multirow[t]{3}{*}{$p \mathrm{CO}_{2}-2(\mu \mathrm{atm})$} & $C_{\mathrm{T}}$ and $\mathrm{pH}_{\mathrm{T}}$ & 11 & 4 & 14 & 11 & 13 & 9 & 12 & 5 \\
\hline & $A_{\mathrm{T}}$ and $\mathrm{pH}_{\mathrm{T}}$ & 11 & 4 & 14 & 10 & 13 & 9 & 12 & 5 \\
\hline & $C_{\mathrm{T}}$ and $A_{\mathrm{T}}$ & 12 & 1 & 28 & 23 & 13 & 3 & 12 & 0 \\
\hline \multirow[t]{5}{*}{$\mathrm{pH}_{\mathrm{T}}$} & $C_{\mathrm{T}}$ and $A_{\mathrm{T}}$ & 0.008 & 0.001 & 0.022 & -0.016 & 0.007 & 0.004 & 0.007 & 0.002 \\
\hline & $A_{\mathrm{T}}$ and $p \mathrm{CO}_{2-1}$ & 0.006 & 0.002 & 0.010 & 0.008 & 0.009 & 0.007 & 0.007 & 0.003 \\
\hline & $C_{\mathrm{T}}$ and $p \mathrm{CO}_{2-1}$ & 0.006 & 0.004 & 0.012 & 0.012 & 0.009 & 0.009 & 0.007 & 0.005 \\
\hline & $A_{\mathrm{T}}$ and $p \mathrm{CO}_{2}-2$ & 0.013 & 0.004 & 0.015 & 0.010 & 0.015 & 0.009 & 0.013 & 0.005 \\
\hline & $C_{\mathrm{T}}$ and $p \mathrm{CO}_{2}-2$ & 0.014 & 0.004 & 0.018 & 0.013 & 0.016 & 0.010 & 0.014 & 0.006 \\
\hline \multirow[t]{3}{*}{$A_{\mathrm{T}}\left(\mu \mathrm{mol} \mathrm{kg} g^{-1}\right)$} & $C_{\mathrm{T}}$ and $\mathrm{pH}_{\mathrm{T}}$ & 4.4 & -0.2 & 12.4 & 9.0 & 3.9 & -1.8 & 4.0 & -1.1 \\
\hline & $C_{\mathrm{T}}$ and $p \mathrm{CO}_{2-1}$ & 4.6 & 2.1 & 17.8 & 16.3 & 5.8 & 3.5 & 4.4 & 1.8 \\
\hline & $C_{\mathrm{T}}$ and $p \mathrm{CO}_{2}-2$ & 8.6 & 0.4 & 20.0 & 14.5 & 9.6 & 1.8 & 8.5 & 0.1 \\
\hline \multirow[t]{3}{*}{$C_{\mathrm{T}}\left(\mu \mathrm{mol} \mathrm{kg}{ }^{-1}\right)$} & $A_{\mathrm{T}}$ and $\mathrm{pH}_{\mathrm{T}}$ & 4.0 & 0.2 & 11.4 & -8.3 & 3.6 & 1.6 & 3.7 & 1.0 \\
\hline & $A_{\mathrm{T}}$ and $p \mathrm{CO}_{2-1}$ & 3.9 & -1.7 & 14.8 & -13.6 & 4.9 & -3.0 & 3.7 & -1.5 \\
\hline & $A_{\mathrm{T}}$ and $p \mathrm{CO}_{2}-2$ & 7.2 & -0.3 & 16.5 & -12.1 & 8.0 & -1.5 & 7.1 & -0.1 \\
\hline
\end{tabular}

* These columns have the same units as the first column. 


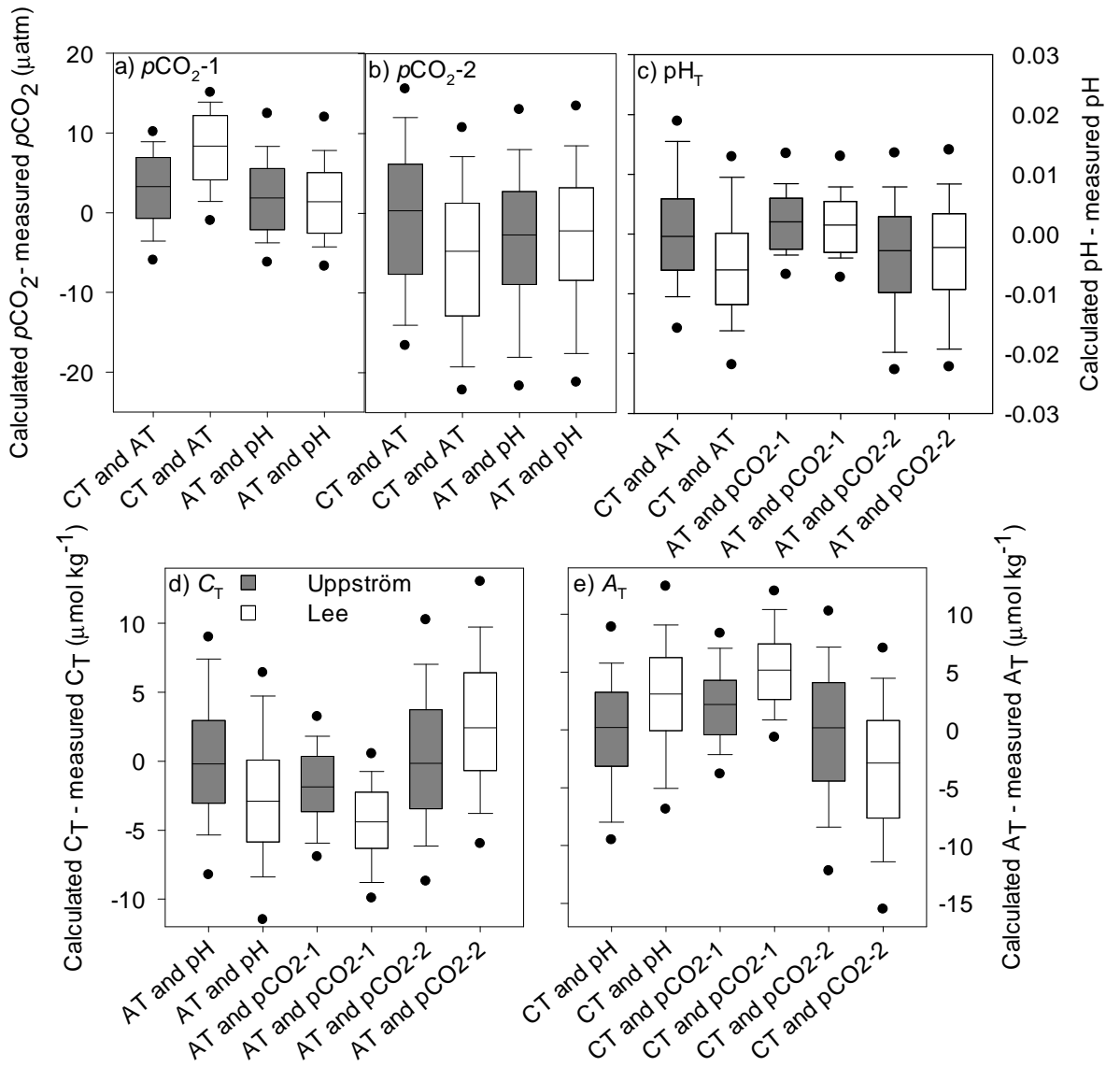

Figure 6. Box-and-whisker plots of the residuals between measured $p \mathrm{CO}_{2}-1$ (a), $p \mathrm{CO}_{2}-2$ (b), $\mathrm{pH}_{\mathrm{T}}$ (c), $C_{\mathrm{T}}$ (d), $A_{\mathrm{T}}$ (e) and the respective estimates calculated from different pairs of measured variables (denoted on the $x$ axis) for the two sets of ratios of total boron to salinity. Grey plots depict the distributions of residuals using the constants of Uppström (1974), and white plots denote those using Lee et al. (2010). The boxes show the median and the 25th and 75th percentiles; dots are the 5th and 95th percentiles. Table 2 presents the RMSE and MR.

using Roy's constants to calculate $\mathrm{pH}_{\mathrm{T}}$ from $C_{\mathrm{T}}$ and $A_{\mathrm{T}}$ (Table 3). McElligott et al. (1998) noted that all four $\mathrm{CO}_{2}$ parameters measured during the NOAA Equatorial Pacific $\mathrm{CO}_{2}$ cruises were internally consistent when using the constants of Mehrbach et al. (1973) refitted by Dickson and Millero (1987) at $20-25^{\circ} \mathrm{C}$, if spectrophotometric $\mathrm{pH}_{\mathrm{T}}$ values were increased by 0.0038 (value proposed by DelValls and Dickson, 1998).

For calculations of $C_{\mathrm{T}}$ and $A_{\mathrm{T}}$, the constants by Roy led to a mean residual further from 0 (statistically significant) than using Mehrbach (large differences between paired values). The reasons for the occasional significant differences between constants are not entirely clear, and investigating the discrepancies is beyond the scope of this work. Objective comparison of the constants is difficult because of differences between the ranges of temperature and salinity over which the constants were measured, and the curve fitting procedures differed (Wanninkhof et al., 1999).

The constants by Mehrbach were determined in artificial seawater using the seawater $\mathrm{pH}$ scale with a range in tem- perature between 2 and $35^{\circ} \mathrm{C}$ and in salinity between 20 and 40. The constants by Lueker were measured in natural seawater using the total $\mathrm{pH}$ scale with a range in temperature of $2-35^{\circ} \mathrm{C}$ and in salinity of $19-43$. Lueker et al. (2000) converted the constants by Mehrbach to the total hydrogen ion $\mathrm{pH}$ scale. The constants by Roy were measured in artificial seawater using the total $\mathrm{pH}$ scale with a range in temperature of $0-45^{\circ} \mathrm{C}$ and in salinity of $5-45$. The constants by Roy have been used for studies in Polar waters (Jutterström and Anderson, 2005; Chierici et al., 2011). The constants by Millero were measured in natural seawater using the seawater $\mathrm{pH}$ scale with a range in temperature of $0-50^{\circ} \mathrm{C}$ and in salinity of 1-50. Dickson et al. (2007) reported that the constants by Lueker were in reasonable agreement with those reported by Roy et al. (1993). In our study, this did not appear to be the case.

Overall, the use of constants by Lueker gave similar results to those of Mehrbach (perhaps unsurprisingly, because they are refitted from constants by Mehrbach), but led to larger mean residuals. Although using constants by Millero 
did not usually lead to statistical differences compared to Mehrbach, the residuals were overall higher than when using either the constants by Mehrbach or Lueker. Our data set confirms that the constants by Mehrbach provided the best quality results, as previously demonstrated by other studies examining the internal consistency in the laboratory (Lee et al., 1996; Lueker et al., 2000) and in the field (Wanninkhof et al., 1999; Lee et al., 2000).

\section{Conclusions}

Our results show that it is possible to obtain good consistency between measurements of different variables of the carbonate system, even outside the somewhat artificial conditions of an intercomparison exercise. However, our retrospective intercomparison revealed several sources of discrepancies, leading to the following recommendation for best practice: (a) undertake characterisation of the $\mathrm{pH}$ indicator dye in order to obtain correct extinction coefficients for the dye and analytical system in the temperature and salinity range used; (b) take into account the transit time of seawater from the intake to the equilibrator, when comparing $p \mathrm{CO}_{2}$ with other simultaneous measurements; (c) examine residuals as a function of time in order to detect temporal biases in measurements; and (d) prevent phototrophic growth in $p \mathrm{CO}_{2}$ equilibrators by completely shielding them from exposure to light.

We obtained smaller average residuals when using the ratio of total boron to salinity from Uppström (1974) rather than Lee et al. (2010), and when using the carbonate constants of Mehrbach et al. (1973) (refitted by Dickson and Millero, 1987) rather than those of Roy et al. (1993), Lueker et al. (2000) or Millero et al. (2006). As found in other studies (Millero, 1995; Cullison Gray et al., 2011), the variables $\mathrm{pH}_{\mathrm{T}}$ and $p \mathrm{CO}_{2}$ are far from an ideal pair for calculation of $C_{\mathrm{T}}$ or $A_{\mathrm{T}}$, emphasising the desirability of developing a $C_{\mathrm{T}}$ or $A_{\mathrm{T}}$ sensor capable of autonomous high-resolution measurements.

Acknowledgements. This work is a contribution to the UK Ocean Acidification Research Programme (UKOA), which is jointly funded by the Department for Environment, Food and Rural Affairs (DEFRA), the Natural Environment Research Council (NERC) and the Department for Energy and Climate Change (DECC) under grant agreement no. NE/H017348/1. We thank the captain and crew of RRS Discovery for assistance during the cruise and N. Wager for her help with e-folding times. N. Greenwood, J.-P. Gattuso and two anonymous reviewers provided valuable comments on earlier versions of this work.

Edited by: J.-P. Gattuso

\section{References}

Bakker, D. C. E., Nielsdóttir, M. C., Morris, P. J., Venables, H. J., and Watson, A. J.: The island mass effect and biological carbon uptake for the subantarctic Crozet Archipelago, Deep-Sea Res. Pt. II, 54, 2174-2190, 2007.

Bakker, D. C. E., Pfeil, B., Smith, K., Hankin, S., Olsen, A., Alin, S. R., Cosca, C., Harasawa, S., Kozyr, A., Nojiri, Y., O’Brien, K. M., Schuster, U., Telszewski, M., Tilbrook, B., Wada, C., Akl, J., Barbero, L., Bates, N. R., Boutin, J., Bozec, Y., Cai, W. J., Castle, R. D., Chavez, F. P., Chen, L., Chierici, M., Currie, K., de Baar, H. J. W., Evans, W., Feely, R. A., Fransson, A., Gao, Z., Hales, B., Hardman-Mountford, N. J., Hoppema, M., Huang, W. J., Hunt, C. W., Huss, B., Ichikawa, T., Johannessen, T., Jones, E. M., Jones, S. D., Jutterström, S., Kitidis, V., Körtzinger, A., Landschützer, P., Lauvset, S. K., Lefèvre, N., Manke, A. B., Mathis, J. T., Merlivat, L., Metzl, N., Murata, A., Newberger, T., Omar, A. M., Ono, T., Park, G. H., Paterson, K., Pierrot, D., Ríos, A. F., Sabine, C. L., Saito, S., Salisbury, J., Sarma, V. V. S. S., Schlitzer, R., Sieger, R., Skjelvan, I., Steinhoff, T., Sullivan, K. F., Sun, H., Sutton, A. J., Suzuki, T., Sweeney, C., Takahashi, T., Tjiputra, J., Tsurushima, N., van Heuven, S. M. A. C., Vandemark, D., Vlahos, P., Wallace, D. W. R., Wanninkhof, R., and Watson, A. J.: An update to the Surface Ocean CO2 Atlas (SOCAT version 2), Earth Syst. Sci. Data, 6, 69-90, 2014, http://www.earth-syst-sci-data.net/6/69/2014/.

Bozec, Y., Thomas, H., Elkalay, K., and de Baar, H. J.: The continental shelf pump for $\mathrm{CO}_{2}$ in the North $\mathrm{Sea}-$ evidence from summer observation, Mar. Chem., 93, 131-147, 2005.

Chierici, M., Fransson, A., Lansard, B., Miller, L. A., Mucci, A., Shadwick, E., Thomas, H., Tremblay, J. E., and Papakyriakou, T. N.: Impact of biogeochemical processes and environmental factors on the calcium carbonate saturation state in the Circumpolar Flaw Lead in the Amundsen Gulf, Arctic Ocean, J. Geophys. Res. Oc. (1978-2012), 116, C00G09, doi:10.1029/2011JC007184, 2011.

Clayton, T. D. and Byrne, R. H.: Spectrophotometric sewater $\mathrm{pH}$ measurements: total hydrogen ion concentration scale calibration of $m$-cresol purple and at sea results, Deep-Sea Res. Pt. I, 40, 2115-2129, 1993.

Clayton, T. D., Byrne, R. H., Breland, J. A., Feely, R. A., Millero, F. J., Campbell, D. M., Murphy, P. P., and Lamb, M. F.: The role of $\mathrm{pH}$ measurements in modern oceanic $\mathrm{CO}_{2}$-system characterizations: Precision and thermodynamic consistency, Deep-Sea Res Pt. II, 42, 411-429, 1995.

Cullison Gray, S. E., DeGrandpre, M. D., Moore, T. S., Martz, T. R., Friederich, G. E., and Johnson, K. S.: Applications of in situ $\mathrm{pH}$ measurements for inorganic carbon calculations, Mar. Chem., 125, 82-90, 2011.

Dickson, A. G.: An exact definition of total alkalinity and a procedure for the estimation of alkalinity and total inorganic carbon from titration data, Deep-Sea Res., 28, 609-623, 1981.

Dickson, A. G.: Standard potential of the reaction $\mathrm{AgCl}(\mathrm{s})+1 / 2 \mathrm{H}_{2}(\mathrm{~g})=\mathrm{Ag}(\mathrm{s})+\mathrm{HCl}(\mathrm{aq})$ and the standard acidity constant of the bisulfate ion in synthetic seawater from $273.15 \mathrm{~K}$ to 318.15 K, J. Chem. Thermodyn., 22, 113-127, 1990a.

Dickson, A. G.: Thermodynamics of the dissociation of boric acid in synthetic seawater from 273.15 to $318.15 \mathrm{~K}$, Deep-Sea Res. Pt A., 37, 755-766, 1990b. 
Dickson, A. G.: Interactive comment on "On $\mathrm{CO}_{2}$ pertubation experiments: over-determination of carbonate chemistry reveals inconsistencies" by Hoppe, C. J. M. Langer, G., Rokitta, S. D., Wolf-Gladrow, D. A., and Rost, B., Biogeosciences Disc., 7, C1286-C1293, 2010.

Dickson, A. G. and Millero, F. J.: A comparison of the equilibrium constants for the dissociation of carbonic acid in seawater media, Deep-Sea Res., 34, 1733-1743, 1987.

Dickson, A. G., Sabine, C. L., and Christian, J. R.: Guide to best practices for ocean $\mathrm{CO}_{2}$ measurements, PICES Special Publication, 3, 175 pp., 2007.

Gabriel, M., Forja, J., Rubio, J., and Gómez-Parra, A.: Temperature and salinity dependence of molar absorptivities of thymol blue: Application to the spectrophotometric determination of $\mathrm{pH}$ in estuarine waters, Cienc. Mar., 31, 309-318, 2005.

Grasshoff, K., Ehrhardt, M., and Kremling, K.: Methods of seawater analysis, Verlag Chemie, Weinheim, Germany, 419 pp., 1983.

Hardman-Mountford, N. J., Moore, G., Bakker, D. C., Watson, A. J., Schuster, U., Barciela, R., Hines, A., Moncoiffé, G., Brown, J., Dye, S., Blackford, J., Somerfield, P. J., Holt, J., Hydes, D. J., and Aiken, J.: An operational monitoring system to provide indicators of $\mathrm{CO}_{2}$-related variables in the ocean, ICES J. Mar. Sci., 65, 1498-1503, 2008.

Hernández-Ayón, J. M., Zirino, A., Dickson, A. G., Camiro-Vargas, T., and Valenzuela-Espinoza, E.: Estimating the contribution of organic bases from microalgae to the titration alkalinity in coastal seawaters, Limnol. Oceanogr.-Meth., 5, 225-232, 2007.

Hopkins, A. E., Sell, K. S., Soli, A. L., and Byrne, R. H.: Insitu spectrophotometric $\mathrm{pH}$ measurements: The effect of pressure on thymol blue protonation and absorbance characteristics, Mar. Chem., 71, 103-109, 2000.

IOCCP: Ocean surface $p \mathrm{CO}_{2}$, data integration and database development, 14-17 January 2004, IOCCP report 2, IOC Worskshop Report 211, available at: http://www.ioccp.org/ images/01Underway/WR211_eo.pdf (last access 28 April 2014), UNESCO Tsukuba, Japan, 2004.

Johnson, K. M., Sieburth, J. M., Williams, P. J. L., and Brandstrom, L.: Coulometric total carbon-dioxide analysis for marine studies - Automation and calibration, Mar. Chem., 21, 117-133, 1987.

Johnson, K. M., Körtzinger, A., Mintrop, L., Duinker, J. C., and Wallace, D. W. R.: Coulometric total carbon dioxide analysis for marine studies: measurement and internal consistency of underway $\mathrm{TCO}_{2}$ concentrations, Mar. Chem., 67, 123-144, 1999.

Juranek, L., Feely, R., Peterson, W., Alin, S., Hales, B., Lee, K., Sabine, C., and Peterson, J.: A novel method for determination of aragonite saturation state on the continental shelf of central Oregon using multi-parameter relationships with hydrographic data, Geophys. Res. Lett., 36, L24601, doi:10.1029/2009GL040778, 2009.

Jutterström, S. and Anderson, L. G.: The saturation of calcite and aragonite in the Arctic Ocean, Mar. Chem., 94, 101-110, 2005.

Katayama, H., Karasudani, T., Ishii, K., Marubayashi, K., and Ueda, H.: Development of a gas-liquid equilibrator for estimating $\mathrm{CO}_{2}$ flux at the ocean surface, J. Atmos. Oc. Technol., 16, 1450-1455, 1999.

Kim, H.-C. and Lee, K.: Significant contribution of dissolved organic matter to seawater alkalinity, Geophys. Res. Lett., 36, L20603, doi:10.1029/2009GL040271, 2009.
Kim, H.-C., Lee, K., and Choi, W.: Contribution of phytoplankton and bacterial cells to the measured alkalinity of seawater, Limnol. Oceanogr., 51, 331-338, 2006.

Kitidis, V., Hardman-Mountford, N. J., Litt, E., Brown, I., Cummings, D., Hartman, S., Hydes, D., Fishwick, J. R., Harris, C., Martinez-Vicente, V., Woodward, E. M. S., and Smyth, T. J.: Seasonal dynamics of the carbonate system in the Western English Channel, Cont. Shelf Res., 42, 30-40, 2012.

Körtzinger, A., Thomas, H., Schneider, B., Gronau, N., Mintrop, L., and Duinker, J. C.: At-sea intercomparison of two newly designed underway $p \mathrm{CO}_{2}$ systems - encouraging results, Mar. Chem., 52, 133-145, 1996.

Körtzinger, A., Mintrop, L., Wallace, D. W. R., Johnson, K. M., Neill, C., Tilbrook, B., Towler, P., Inoue, H. Y., Ishii, M., Shaffer, G., Saavedra, R. F. T., Ohtaki, E., Yamashita, E., Poisson, A., Brunet, C., Schauer, B., Goyet, C., and Eischeid, G.: The international at-sea intercomparison of $f \mathrm{CO}_{2}$ systems during the $\mathrm{R} / \mathrm{V}$ Meteor Cruise 36/1 in the North Atlantic Ocean, Mar. Chem., 72, 171-192, 2000.

Lamb, M. F., Sabine, C. L., Feely, R. A., Wanninkhof, R., Key, R. M., Johnson, G. C., Millero, F. J., Lee, K., Peng, T. H., Kozyr, A., Bullister, J. L., Greeley, D., Byrne, R. H., Chipman, D. W., Dickson, A. G., Goyet, C., Guenther, P. R., Ishii, M., Johnson, K. M., Keeling, C. D., Ono, T., Shitashima, K., Tilbrook, B., Takahashi, T., Wallace, D. W. R., Watanabe, Y. W., Winn, C., and Wong, C. S.: Consistency and synthesis of Pacific Ocean $\mathrm{CO}_{2}$ survey data, Deep-Sea Res Pt. II, 49, 21-58, 2001.

Lee, K., Millero, F. J., and Campbell, D. M.: The reliability of the thermodynamic constants for the dissociation of carbonic acid in seawater, Mar. Chem., 55, 233-245, 1996.

Lee, K., Millero, F. J., and Wanninkhof, R.: The carbon dioxide system in the Atlantic Ocean, J. Geophys. Res.-Oceans., 102, 15693-15707, 1997.

Lee, K., Millero, F. J., Byrne, R. H., Feely, R. A., and Wanninkhof, R.: The recommended dissociation constants for carbonic acid in seawater, Geophys. Res. Lett., 27, 229-232, 2000.

Lee, K., Kim, T. W., Byrne, R. H., Millero, F. J., Feely, R. A., and Liu, Y. M.: The universal ratio of boron to chlorinity for the North Pacific and North Atlantic oceans, Geochim. Cosmochim. Acta, 74, 1801-1811, 2010.

Legendre, P.: Imodel2: Model II Regression, R package version 1.72, http://CRAN.R-project.org/package=lmodel2, 2014.

Lewis, E. and Wallace, D. W. R.: Program developed for $\mathrm{CO}_{2}$ system calculations. ORNL/CDIAC-105, Carbon Dioxide Information Analysis Center, Oak Ridge National Laboratory, US, Department of Energy, Oak Ridge, Tennessee, 1998.

Liu, X., Patsavas, M. C., and Byrne, R. H.: Purification and characterization of meta-cresol purple for spectrophotometric seawater pH measurements, Environ. Sci. Technol., 45, 4862-4868, 2011.

Loucaides, S., Tyrrell, T., Achterberg, E. P., Torres, R., Nightingale, P. D., Kitidis, V., Serret, P., Woodward, M., and Robinson, C.: Biological and physical forcing of carbonate chemistry in an upwelling filament off northwest Africa: Results from a Lagrangian study, Global Biogeochem. Cy., 26, GB3008, doi:10.1029/2011GB004216, 2012.

Lueker, T. J., Dickson, A. G., and Keeling, C. D.: Ocean $p \mathrm{CO}_{2}$ calculated from dissolved inorganic carbon, alkalinity, and equations for $\mathrm{K}_{1}$ and $\mathrm{K}_{2}$ : Validation based on laboratory measure- 
ments of $\mathrm{CO}_{2}$ in gas and seawater at equilibrium, Mar. Chem., 70, 105-119, 2000.

McElligott, S., Byrne, R., Lee, K., Wanninkhof, R., Millero, F., and Feely, R.: Discrete water column measurements of $\mathrm{CO}_{2}$ fugacity and $\mathrm{pH}_{\mathrm{T}}$ in seawater: A comparison of direct measurements and thermodynamic calculations, Mar. Chem., 60, 63-73, 1998.

Mehrbach, C., Culberso, C. H., Hawley, J. E., and Pytkowic, R. M.: Measurement of apparent dissociation constants of carbonic acid in seawater at atmospheric pressure, Limnol. Oceanogr., 18, 897907, 1973

Millero, F. J.: Thermodynamics of the carbon dioxide system in the oceans, Geochim. Cosmochim. Acta, 59, 661-677, 1995.

Millero, F. J.: The marine inorganic carbon cycle, Chem. Rev., 107, 308-341, 2007.

Millero, F. J., Pierrot, D., Lee, K., Wanninkhof, R., Feely, R., Sabine, C. L., Key, R. M., and Takahashi, T.: Dissociation constants for carbonic acid determined from field measurements, Deep-Sea Res. Pt. I, 49, 1705-1723, 2002.

Millero, F. J., Graham, T. B., Huang, F., Bustos-Serrano, H., and Pierrot, D.: Dissociation constants of carbonic acid in seawater as a function of salinity and temperature, Mar. Chem., 100, 8094, 2006.

Mosley, L. M., Husheer, S. L., and Hunter, K. A.: Spectrophotometric $\mathrm{pH}$ measurement in estuaries using thymol blue and $m$-cresol purple, Mar. Chem., 91, 175-186, 2004.

Pfeil, B., Olsen, A., Bakker, D. C. E., Hankin, S., Koyuk, H., Kozyr, A., Malczyk, J., Manke, A., Metzl, N., Sabine, C. L., Akl, J., Alin, S. R., Bates, N., Bellerby, R. G. J., Borges, A., Boutin, J., Brown, P. J., Cai, W. J., Chavez, F. P., Chen, A., Cosca, C., Fassbender, A. J., Feely, R. A., González-Dávila, M., Goyet, C., Hales, B., Hardman-Mountford, N., Heinze, C., Hood, M., Hoppema, M., Hunt, C. W., Hydes, D., Ishii, M., Johannessen, T., Jones, S. D., Key, R. M., Körtzinger, A., Landschützer, P., Lauvset, S. K., Lefèvre, N., Lenton, A., Lourantou, A., Merlivat, L., Midorikawa, T., Mintrop, L., Miyazaki, C., Murata, A., Nakadate, A., Nakano, Y., Nakaoka, S., Nojiri, Y., Omar, A. M., Padin, X. A., Park, G. H., Paterson, K., Perez, F. F., Pierrot, D., Poisson, A., Ríos, A. F., Santana-Casiano, J. M., Salisbury, J., Sarma, V. V. S. S., Schlitzer, R., Schneider, B., Schuster, U., Sieger, R., Skjelvan, I., Steinhoff, T., Suzuki, T., Takahashi, T., Tedesco, K., Telszewski, M., Thomas, H., Tilbrook, B., Tjiputra, J., Vandemark, D., Veness, T., Wanninkhof, R., Watson, A. J., Weiss, R., Wong, C. S., and Yoshikawa-Inoue, H.: A uniform, quality controlled Surface Ocean $\mathrm{CO}_{2}$ Atlas (SOCAT), Earth Syst. Sci. Data, 5, 125-143, doi:10.5194/essd-5-125-2013, 2013.

Pierrot, D., Neill, C., Sullivan, K., Castle, R., Wanninkhof, R., Lüger, H., Johannessen, T., Olsen, A., Feely, R. A., and Cosca, C. E.: Recommendations for autonomous underway $p \mathrm{CO}_{2}$ measuring systems and data-reduction routines, Deep-Sea Res Pt. II, 56, 512-522, 2009.

Poulton, A. J., Stinchcombe, M. C., Achterberg, E. P., Bakker, D. C. E., Dumousseaud, C., Lawson, H. E., Lee, G. A., Richier, S., Suggett, D. J., and Young, J. R.: Coccolithophores on the northwest European shelf: calcification rates and environmental controls, Biogeosciences, 11, 3919-3940, doi:10.5194/bg-11-39192014, 2014.
Quinn, G. P. and Keough, M. J.: Experimental design and data analysis for biologists, Cambridge University Press, 2002.

Rérolle, V., Floquet, C. F., Harris, A. J., Mowlem, M. C., Bellerby, R. R., and Achterberg, E. P.: Development of a colorimetric microfluidic $\mathrm{pH}$ sensor for autonomous seawater measurements, Anal. Chim. Acta, 786, 124-131, 2013.

Rérolle, V. M. C., Floquet, C. F. A., Mowlem, M. C., Bellerby, R., Connelly, D. P., and Achterberg, E. P.: Seawater-pH measurements for ocean-acidification observations, Trends Anal. Chem., 40, 146-157, 2012.

Rérolle, V. M. C., Ribas-Ribas, M., Kitidis, V., Brown, I., Bakker, D. C. E., Lee, G. A., Shi, T., Mowlem, M. C., and Achterberg, E. P.: Controls on $\mathrm{pH}$ in surface waters of northwestern European shelf seas, Biogeosciences Discuss., 11, 943-974, doi:10.5194/bgd11-943-2014, 2014.

Ribas-Ribas, M., Rérolle, V. M. C., Kitidis, V., Bakker, D. C. E., Lee, G. A., Brown, I., Hardman-Mountford, N., Stinchcombe, M. C., and Palmer, M. R.: UK Ocean Acidification programme surface carbonate chemistry measurements from D366 cruise around the British Isles, British Oceanographic Data Centre Natural Environment Research Council, UK, 2014.

Roy, R. N., Roy, L. N., Vogel, K. M., Porter-Moore, C., Pearson, T., Good, C. E., Millero, F. J., and Campbell, D. M.: The dissociation constants of carbonic acid in seawater at salinities 5 to 45 and temperatures 0 to 45 C, Mar. Chem., 44, 249-267, 1993.

Schuster, U. and Watson, A. J.: A variable and decreasing sink for atmospheric $\mathrm{CO}_{2}$ in the North Atlantic, J. Geophys. Res.Oceans, 112, C11006, doi:10.1029/2006jc003941, 2007.

Takahashi, T., Olafsson, J., Goddard, J. G., Chipman, D. W., and Sutherland, S. C.: Seasonal variation of $\mathrm{CO}_{2}$ and nutrients in the high-latitutde surface oceans- A comparative study., Global Biogeochem. Cy., 7, 843-878, 1993.

Uppström, L. R.: The boron/chlorinity ratio of deep-sea water from the Pacific Ocean, Deep-Sea Res. Oceanogr. Abstr., 21, 161-162, 1974.

Van Heuven, S., Pierrot, D., Rae, J. W. B., Lewis, E., and Wallace, D. W. R.: CO2SYS v 1.1, MATLAB program developed for $\mathrm{CO}_{2}$ system calculations, ORNL/CDIAC-105b. Carbon Dioxide Information Analysis Center, Oak Ridge National Laboratory, US DoE, Oak Ridge, TN, 2011.

Wanninkhof, R., Lewis, E., Feely, R. A., and Millero, F. J.: The optimal carbonate dissociation constants for determining surface water $p \mathrm{CO}_{2}$ from alkalinity and total inorganic carbon, Mar. Chem., 65, 291-301, 1999.

Wanninkhof, R., Bakker, D. C. E., Bates, N., Olsen, A., Steinhoff, T., and Sutton, A. J.: Incorporation of Alternative Sensors in the SOCAT Database and Adjustments to Dataset Quality Control Flags, http://cdiac.ornl.gov/oceans/ Recommendationnewsensors.pdf, Carbon Dioxide Information Analysis Center, Oak Ridge National Laboratory, US Depart. Energy, doi:10.3334/CDIAC/OTG.SOCAT_ADQCF, 2013.

Weiss, R. F. and Price, B. A.: Nitrous-oxide solubility in water and seawater, Mar. Chem., 8, 347-359, 1980.

Yao, W., Liu, X., and Byrne, R. H.: Impurities in indicators used for spectrophotometric seawater $\mathrm{pH}$ measurements: Assessment and remedies, Mar. Chem., 107, 167-172, 2007. 
Young, J. R., Poulton, A. J., and Tyrrell, T.: Morphology of Emiliania huxleyi coccoliths on the North West European shelf - is there an influence of carbonate chemistry?, Biogeosciences Discuss., 11, 4531-4561, doi:10.5194/bgd-11-4531-2014, 2014.
Zhang, H. N. and Byrne, R. H.: Spectrophotometric $\mathrm{pH}$ measurements of surface seawater at in-situ conditions: Absorbance and protonation behavior of thymol blue, Mar. Chem., 52, 17-25, 1996. 